\author{
UNIVERSIDADE DE SÃO PAULO \\ FACULDADE DE ECONOMIA, ADMINISTRAÇÃO E CONTABILIDADE \\ DEPARTAMENTO DE ECONOMIA \\ PROGRAMA DE PÓS-GRADUAÇÃO EM ECONOMIA
}

\title{
The Impact of Trade Shock Exposure on Child Labor and Schooling in Brazil
}

\author{
Arthur Augusto Viaro
}

Orientador: Prof. Dr. Marcos Yamada Nakaguma

São Paulo 
Prof. Dr. Marco Antonio Zago

Reitor da Universidade de São Paulo

Prof. Dr. Adalberto Américo Fischmann

Diretor da Faculdade de Economia, Administração e Contabilidade

Prof. Dr. Eduardo Amaral Haddad

Chefe do Departamento de Economia

Prof. Dr. Ariaster Baumgratz Chimeli

Coordenador do Programa de Pós-Graduação em Economia 


\section{The Impact of Trade Shock Exposure on Child Labor and Schooling in Brazil}

Dissertação apresentada ao Departamento de Economia da Faculdade de Economia, Administração e Contabilidade da Universidade de São Paulo como requisito parcial para a obtenção do título de Mestre em Ciências.

Orientador: Prof. Dr. Marcos Yamada Nakaguma

Versão Original

São Paulo 
FICHA CATALOGRÁFICA

Elaborada pela Seção de Processamento Técnico do SBD/FEA/USP

Viaro, Arthur Augusto

The impact of trade shock exposure on child labor and schooling in Brazil / Arthur Augusto Viaro. - São Paulo, 2017.

$63 \mathrm{p}$.

Dissertação (Mestrado) - Universidade de São Paulo, 2017.

Orientador: Marcos Yamada Nakaguma.

1. Trabalho infantil 2. Frequência escolar 3. Comércio internacional I. Universidade de São Paulo. Faculdade de Economia, Administração e Contabilidade. II. Título.

CDD - 331.31 
Aos meus pais 


\section{Acknowledgements}

Agradeço primeiramente ao meu orientador, o professor Marcos Nakaguma, pelo incentivo e dedicação ao longo de todo o desenvolvimento deste trabalho. Sou grato a todos os professores da FEA-USP que contribuíram para a minha formação nos cursos de graduação e pós-graduação. Agradeço, em especial, aos professores Fernanda Estevan, Ricardo Madeira e Raphael Corbi pelos valiosos comentários que muito me ajudaram na elaboração desta pesquisa.

Agradeço, ainda, a todas as pessoas que passaram pela minha vida ao longo destes anos na Universidade de São Paulo. Cada um a sua maneira contribuiu para que o caminho até aqui fosse muito mais alegre e enriquecedor. Agradeço especialmente ao Felipe Trentin, um amigo que desde os tempos de graduação sempre contribuiu para o meu crescimento pessoal e profissional com longas conversas e sábios conselhos.

Agradeço aos meus pais e a minha irmã pelo amor e confiança que sempre depositaram em mim.

Sou grato ao CNPq pela bolsa de estudos concedida durante o mestrado. 
"A tarefa não é tanto ver aquilo que ninguém viu, mas pensar o que ninguém ainda pensou sobre aquilo que todo mundo vê." 


\section{Resumo}

Trabalho infantil ainda é um problema relevante nos países em desenvolvimento e entender o modo como as famílias respondem a incentivos no mercado de trabalho decidindo como alocar o tempo das crianças tem importantes implicações em termos de política. Neste trabalho, eu exploro um choque plausivelmente exógeno sobre o mercado de trabalho causado pelo comércio internacional para avaliar como mudanças no retorno do trabalho afetam a alocação de tempo das crianças no Brasil. Para medir mudanças exógenas sobre os retornos do trabalho adulto e infantil, eu proponho uma estratégia que distingue entre choques no emprego que afetam diferentemente adultos e crianças. Os resultados sugerem um efeito assimétrico sobre as decisões das famílias com relação à alocação de tempo das crianças a depender da fonte do choque. Primeiramente, choques de importação sobre os trabalhadores adultos diminuem a proporção de crianças na escola, enquanto choques adversos sobre as crianças que trabalham têm um efeito positivo sobre a escolaridade, mas as estimativas não são estatisticamente significantes. Por outro lado, ambos os choques diminuem a proporção de crianças trabalhando. Entretanto, choques sobre os adultos aumentam a ociosidade, enquanto choques sobre as crianças aumentam a dedicação exclusiva aos estudos. Eu forneço evidências de que a pobreza e a composição do emprego são dois possíveis mecanismos por trás dos resultados. Eu encontro ainda que choques adversos nas crianças possuem efeitos positivos sobre a proficiência em matemática no exame nacional de avaliação do ensino básico (Saeb) e que os efeitos são mais fortes em crianças que moram nas áreas rurais.

Palavras-chave: Trabalho infantil, Frequência escolar, Comércio internacional 


\section{Abstract}

Child labor is still a relevant problem in developing countries and understanding the way that households respond in terms of children's time allocation to labor market incentives has relevant policy implications. In this paper, I explore a plausibly exogenous trade-induced labor market shock to assess how changes in returns to work affect children's time allocation in Brazil. To provide a good proxy for distinctly exogenous changes to the returns to adult labor as well as returns to the child labor I propose a strategy that distinguish between employment shocks that differentially affect adults and children. The results suggest an asymmetric impact on household decisions about children's time allocation that depend upon the source of the shock. First, larger import competition shocks concentrated on adult workers decrease the share of children that attend school, while an adverse shock concentrated on child workers has a positive effect on schooling, but the estimates are not statistically significant. On the other hand, both shocks decrease the share of working children. However, shocks on adults increase idleness, while shocks on children increase full-time schooling. I provide evidence that poverty and employment composition pattern are two possible mechanisms behind the results. I also find that adverse shocks on children have positive effects on math scores in a standardized national exam (Saeb) and stronger effects for children living in rural areas.

Keywords: Child labor, School attendance, International trade 


\section{List of Figures}

Figure 1 - Geographical distributions of the trade shock measures across Brazilian

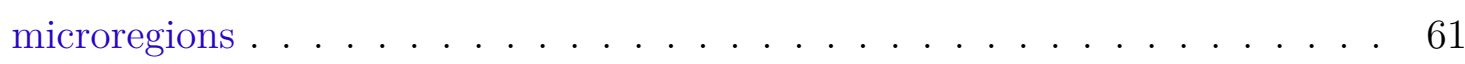

Figure 2 - Distributions of overall and disaggregated trade shocks measures . . . . . . 62 


\section{List of Tables}

Table 1 - Summary statistics - Children activities . . . . . . . . . . 26

Table 2 - Summary statistics - Chinese trade shock measures (overall and age-specific

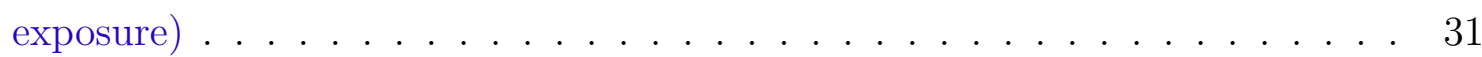

Table 3 - Main results - The effects of trade shocks on school attendance and child labor 36

Table 4 - Main results - The effects of trade shocks on children activities . . . . . . 38

Table 5 - Main results - The effects of trade shocks on school performance . . . . . . 39

Table 6 - Main results - The effects of trade shocks on school quality/quantity . . . . . 41

Table 7 - Mechanisms - The effects of trade shocks on poverty measures . . . . . . . . 44

Table 8 - Mechanisms - The effects of trade shocks on employment composition patterns 45

Table 9 - Heterogeneous effects - The effects of trade shocks on children living in ur-

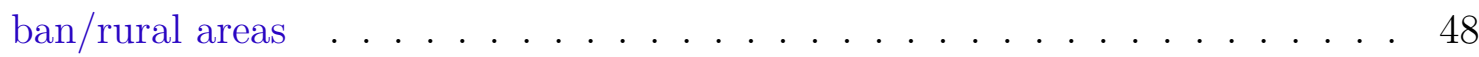

Table 10 - Heterogeneous effects - The effects of trade shocks on school performance in

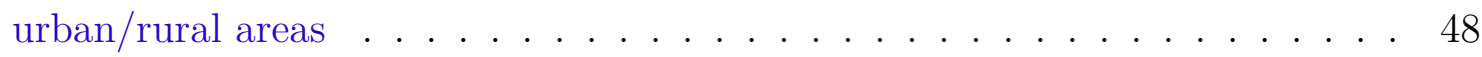

Table A1 - Robustness regressions - The effects of trade shocks on children activities . . 56

Table A2 - Robustness regressions - The effects of trade shocks on children activities (alternative measures for trade shock exposure) . . . . . . . . . . . . . 56

Table B1 - Additional summary statistics - Child labor intensity and trade exposure measures by sector . . . . . . . . . . . . . . . 57

Table B2 - First-stage estimates (Main results) - Overall trade shocks . . . . . . . . . . 60

Table B3 - First-stage estimates (Main results) - Disaggregated trade shocks . . . . . . . 61 


\section{Contents}

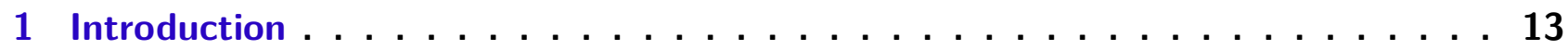

2 Theoretical Framework . . . . . . . . . . . . . . . . . . . 19

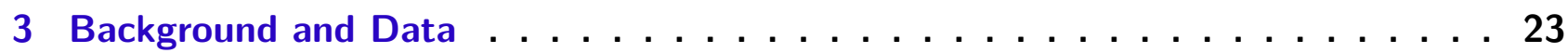

3.1 Child Labor and School Attendance in Brazil . . . . . . . . . . . . . . . 23

3.2 China Trade Shock . . . . . . . . . . . . . . . . . . . . . . 24

3.3 Data and Summary Statistics _. . . . . . . . . . . . . . . 25

4 Empirical Strategy . . . . . . . . . . . . . . . . . . . . . 29

4.1 Measuring Trade Shocks . . . . . . . . . . . . . . . . . . . . . . . . . 29

$4.2 \quad$ Empirical Framework . . . . . . . . . . . . . . . . . . . . . . . 32

5 Main Results . . . . . . . . . . . . . . . . . . . 35

5.1 Impact of Trade Shock on Children Activities . . . . . . . . . . . . . 35

5.2 Impact of Trade Shock on School Outcomes _ . . . . . . . . . . . . . 38

6 Mechanisms . . . . . . . . . . . . . . . . . . 43

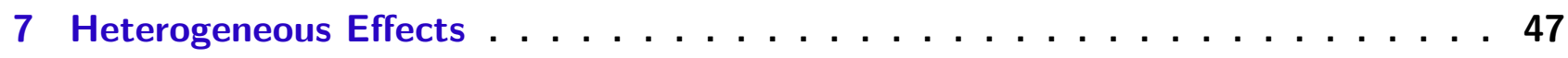

8 Concluding Remarks . . . . . . . . . . . . . . . . . . 49

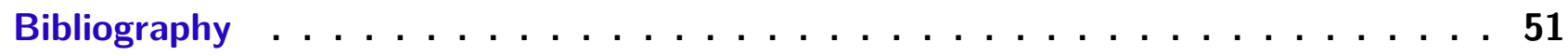

Appendix A . . . . . . . . . . . . . . . . 55

Appendix B . . . . . . . . . . . . . . . . 57 



\section{Introduction}

Despite the significant decline in the last decades, child labor is still a relevant problem in developing countries. According to International Labor Organization (2013), almost 11\% of the world child population between the ages of 5 and 17 were working in 2012. In economics, one of the most harmful effects of child labor is that it can be an important intergenerational source of poverty trap ${ }^{1}$, which means that children who work have lower levels of educational attainment and earn lower wages latter in life, as suggested by the empirical evidence presented by Emerson e Souza (2003). Therefore, understanding the way that households respond in terms of children's time allocation to labor market incentives has relevant policy implications. Linking labor market changes to children's time allocation, however, is extremely difficult because changes in labor earnings affect both adults and children, making the great disparity of empirical results looking like a "puzzle" in a first sight.

There is, for example, a lot of evidence that supports a negative relationship between poverty and child labor as theorized by Basu e Van (1998). Beegle, Dehejia e Gatti (2006) show that negative agricultural shocks increase the number of hours worked by children in Tanzania and reduce school enrollment, while Edmonds e Pavcnik (2005) find that higher rice prices due to the end of export quotas in Vietnam are associated with large declines in child labor. Examining the Indian 1991 tariff reform, Edmonds, Pavcnik e Topalova (2010) find smaller increases in schooling in rural districts most exposed to trade liberalization. On the other hand, various empirical studies using Latin American data find a positive relationship between income and child labor. Using the value of Brazil's county coffee production as a proxy for local economic conditions, Kruger (2007) finds that periods of economic growth lead to more child labor and less schooling. Similarly, Duryea e Arends-Kuenning (2003) find that work among 14-16 year old children increases in urban Brazil as local labor market opportunities improve, while schooling outcomes get worse. In the Indian context, Rosenzweig e Evenson (1977) also find that child wages are positive correlated to children employment and negative related to school enrollment.

As appointed by Soares, Kruger e Berthelon (2012), the conflicting results from the

$1 \quad$ For a theoretical analysis of intergenerational child labor traps see, e.g., Baland e Robinson (2000). 
empirical literature are consistent with theory and are a consequence of the incapacity to distinguish between the income and substitution effects implicit in different types of income variation. In particular, theory predicts that smaller returns to adult labor should decrease children's schooling outcomes and increase child labor if education is a normal good. This is known as the income effect. On the other hand, changes in returns to child labor are associated with changes in the opportunity cost of children's time and have both income and substitution effects, which means that the net effect depends on the relative size of each mechanism. If income effect is large, then children may be pulled out of school and may work more hours during negative shocks. But if, on the other hand, substitution effect is sufficient strong, a negative income shock may improve schooling and reduce child labor. Therefore, the overall effect of changes in local economic conditions on children's time allocation is ambiguous and it is an empirical challenge to unbundle exogenous changes to the returns to adult labor as well as exogenous changes to the returns to child labor.

In this paper, I explore how changes in returns to work affect children's time allocation using a novel strategy to distinguish between employment shocks that differentially affect adult and child labor. Specifically, I relate changes in child labor and school attendance rates from 2000 to 2010 across Brazilian microregions to changes in labor market opportunities for adults and children. Then, the main innovation of the paper is to exploit differences in industry employment composition by age to identify whether shocks to returns to adult and child labor produce asymmetric effects on children's time allocation. In order to identify exogenous shocks to local labor market opportunities, I follow Autor, Dorn e Hanson (2013) and Costa, Garred e Pessoa (2016) and take advantage of the China's rapidly rising trade integration as a quasi-natural experiment.

The identification strategy is motivated by the asymmetric effect that China's export and import growth has had on local labor markets in Brazil. I compute measures for the exposure of each Brazilian microregion to the Chinese import and export shocks between 2000 and 2010 combining information on trade flows at the country level with data on the sectoral composition of employment in each microregion. The basic intuition is that different microregions have been more or less exposed to the rise of China as a major player in international trade depending on 
their pre-shock industry specialization. In particular, the Chinese shock has been stronger in those microregions in which larger share of workers was employed in industries that subsequently registered a higher growth in exports (imports) to (from) China. To ensure that these trade shock measures are neither capturing Brazil-specific shocks nor changes in world prices that are not directly due to China, I follow Costa, Garred e Pessoa (2016) and use an instrumental variable that depends on growth in trade between China and countries other than Brazil.

To separately identify exogenous changes to the returns to adult labor as well as an exogenous change to the returns to child labor, holding family income constant, I explore the richness of the Brazilian Demographic Census data to compute measures for the trade shock exposure of each Brazilian microregion according to the relative importance of adult and child employment intensity; hence, trade shocks of a given magnitude will differentially affect adult and child depending on the set of sectors that are exposed. Most closely related to the present paper is a recent work by Bai (2016), who exploits 1991 Indian tariff reform to examine the impact of losing tariff protection on children activities. To my knowledge, the author is the first one to propose a strategy to identify income and substitution effects computing disaggregated tariff measures according to adult and child labor-intensive sectors. The advantage of my strategy, however, is that it captures a directly children exposure to trade shock since it takes into account the geographical distribution of working children across Brazilian microregions. This is possible because data from Brazilian Demographic Census allows me to exploit the spatial distribution of children across microregions and sectors, which is a better approach to identify the labor market shocks that directly affect children.

The results suggest an asymmetric impact on household decisions about children's time allocation that depend upon the source of the shock. First, I find that larger import competition shocks to adult and child-intensive sectors have opposite signed effects on school attendance. Conditional on child labor market shocks, larger import competition shocks concentrated on adult employment decrease the share of children that attend school, while conditional on adult labor market shocks, an adverse shock concentrated on children has a positive effect on schooling, but the estimates are not statistically significant. On the other hand, both shocks decrease the share of working children, in particular those who combine work and school. However, shocks 
on adults increase idleness, while shocks on children increase the share of children that attend school full-time. These basic results hold even when I control for pre-sample period trends or compute alternative trade shock measures. On the other hand, I find no robust evidence that export demand shocks affect schooling and child labor outcomes.

Having demonstrated the asymmetric effects of trade-induced labor market changes on decisions of time allocation, I then examine if there is any effect on school performance and find that import competition shocks on children is associated with an increase in microregion's average math scores in a standardized national exam (Saeb) between 2001 and 2011. The child labor research has mainly focused on the trade-off between time spent at school and working, therefore this exercise is a first attempt to contribute to the growing literature on the consequences of child labor on the quality of schooling. Next, I explore the mechanisms behind the results and distinguish two possibilities. First, if the exposure to the import competition shock is associated with increases in poverty, schooling could decline. Second, changes in the composition of local employment across sectors in response to trade shocks may explain why children dropout labor market even when adults are exposed to adverse shocks. I provide evidence of both mechanisms and show that import competition shocks are associated with lower children's wages, lower household income per capita and higher share of children living in vulnerable conditions. On the other hand, adverse shocks on adults increase (decrease) the share of adults (children) employed in agriculture, which is the most important sector for child labor. The result is an evidence of the movement of adult workers from manufacturing sectors into children vacancies in agriculture, which may explain the decline in the share of working children between 2000 and 2010. Finally, I examine whether the effects are heterogeneous for children living in urban and rural households and I find that adverse import competition shocks have a strong effect for rural children, but not for the urban ones.

Brazil provides an excellent setting to study the effects of trade-induced labor market changes on household decisions. First, despite the success in adopting policies in order to eliminate child labor, the number of working children in the country is still high, specially in lower socioeconomic groups (Barros e Mendonça (2010)). Second, the importance of China in both the Brazilian imports and exports has risen steeply in recent years. In 2010 China 
was Brazil's largest trading partner, accounting for over 16.0\% of total Brazilian exports and supplying over $14.0 \%$ of its imports (in 2000, these shares were approximately $2.0 \%$ ). Third, Brazil is a large country and the Brazilian Demographic Census for 2000 and 2010 used in the empirical analysis allows me to exploit the geographical distribution of child labor, capturing the great heterogeneity that exists across Brazilian microregions.

A specific contribution of this paper to the child labor literature is to explore differences in industry specialization by age to identify trade shocks that differently affect adult's and child's employment outcomes. The strategy proposed gives a good measure of exogenous changes to the returns to adult labor as well as returns to the child labor, allowing me to deal with the "puzzle" in the previous literature and to better understand household decisions regarding children's time allocation (e.g., Soares, Kruger e Berthelon (2012); Beegle, Dehejia e Gatti (2006); Edmonds e Pavcnik (2005); Edmonds, Pavcnik e Topalova (2010); Bai (2016); Kruger (2007); Duryea e Arends-Kuenning (2003); Rosenzweig e Evenson (1977)). A related work that exploits a similar approach is Greenland e Lopresti (2016), who document large increases in U.S. high school graduation rates in the labor markets most affected by import competition. Using variation in the timing of export manufacturing plant openings across local regions in Mexico, Atkin (2016) also studies the impacts of globalization on the labor force and finds higher school dropout rates due to the increased job market opportunities. This paper also contributes to the growing literature on the consequences of child labor on the quality of schooling (e.g., Emerson, Ponczek e Souza (2017); Zabaleta (2011); Dumas (2012)) and to the literature on the effects of trade on local labor markets (e.g., Autor, Dorn e Hanson (2013); Topalova (2010); Acemoglu et al. (2016); Gonzaga, Filho e Terra (2006); Dix-Carneiro e Kovak (2015)).

The remainder of the paper is organized as follows: Section 2 provides a theoretical model of household decisions regarding children's time allocation. Section 3 describes the data used in the empirical analysis and the background of the trade integration between Brazil and China, as well as the evolution of child labor and schooling in Brazil. Section 4 presents the empirical strategy. Section 5 presents and discusses the main results. Section 6 explores the mechanisms behind the results. Section 7 investigates heterogeneous effects for children living in urban and rural households. Finally, Section 8 concludes. 



\section{Theoretical Framework}

This section presents a simple model of household decision for children's time allocation in order to guide the interpretation of the empirical analysis. The model is the same as developed by Biggeri et al. (2003) and has the advantage of including an important alternative choice for children's time use that is observed in data: idleness. The group of children absent from both school and economic activity also constitute an important policy concern, then it is necessary to see if economic theory can justify this allocation option.

Consider an economy where parents make all decisions. To simplify, assume that households have only one parent and one child. The household's utility function is given by

$$
U=u(x, H)
$$

where $x$ is household consumption and $H$ is the child stock of human capital. Assume that children's time (normalized to 1) can be allocated to either work, $l$, or to the accumulation of human capital by attending school according to the following function:

$$
H=h_{0}+g(1-l), \quad g^{\prime}>0,
$$

where $h_{0}$ indicates the innate stock of human capital and $g^{\prime}$ is the (marginal) return to education. Consumption goods are purchased with income from adult and child labor. Assume yet that parents participate fully in the labor market, that is, their labor supply is inelastic and normalized to 1 . Then, parent's income is given by $w_{p}$, the adult wage ${ }^{1}$. Income from child labor is given by $w_{c} l$, where $w_{c}$ is the child wage (or the return to work).

Biggeri et al. (2003) also assume that there is a fixed cost of $S$ associated with schooling which must be paid by the household only when children attend school. These costs are influenced

$\overline{1}$ As noted by Soares, Kruger e Berthelon (2012), the adult wage depends on the level of human capital previously accumulated by the parent. Although Biggeri et al. (2003) do not deal with this explicitly in their model, it can be a reason why parents attach positive value to the human capital of the child in the utility function. 
by the quality of the school system and by the labor market. The authors also consider a fixed cost of $Z$ associated with working, which is paid only when household send children to work. This cost can be thought, for example, as transportation costs, the costs related to the job search or indirect costs like health risks. These costs are also influenced by the institutional framework. While the size of these fixed costs is crucial for the decision to enter the labor market or to attend school, it will not affect the choice of hours worked or invested in human capital accumulation once entry has been made. Since a non-convexity of the budget set is introduced through the presence of these fixed costs, the authors consider four different cases in order to determine the optimal choice of the household:

1. First case: Work and No Schooling

If child works full-time the maximum level of utility that the household can obtain is:

$$
l=1 \Rightarrow U_{w}^{*}=u\left(w_{p}+w_{c}-Z, h_{0}\right)
$$

2. Second case: Work and Schooling

If child works and attends school part-time the indirect utility function is:

$$
0<l<1 \Rightarrow U_{w s}^{*}=u\left(w_{p}+w_{c} l-Z-S, h_{0}+g(1-l)\right)
$$

3. Third case: Schooling and No Work

If child attends school and does not work the utility is:

$$
l=0 \Rightarrow U_{s}^{*}=u\left(w_{p}-S, h_{0}+g(1)\right)
$$

4. Fourth case: Idleness

If child does not work and does not attend school the indirect utility is:

$$
l=0 \Rightarrow U_{i}^{*}=u\left(w_{p}, h_{0}\right)
$$

As discussed by Biggeri et al. (2003), the decision of household among these four possible states will depend on its preferences and on the relative prices that include the returns to work $\left(w_{p}\right.$ and $\left.w_{c}\right)$, the returns to education $\left(g^{\prime}\right)$, the fixed costs of working $(Z)$, and the costs of 
attending school $(S)$. Note that a child who does not attend school will also not work if the fixed costs of work, $Z$, is higher than the return to work. We can imagine, for example, an increase in the costs associated with job searching. In particular, one possibility is that in response to adverse shocks, adult workers might be reallocated to sectors in which children typically work. This employment composition changes can raise the costs of searching for a job, making it more difficult for children to enter the labor market. Then, to observe idle children, it is necessary low returns (high costs) of education and low returns (high costs) to work.

This simple model gives some interesting predictions about household decisions about children's time allocation. First, an increase in the return to work (or a reduction in the fixed costs to work) will make more likely that a child works and less likely that he attends school or lays idle. Analogously, higher returns to education (or lower costs of education) makes more likely that a child attends school and does not work. In the empirical section I test some of these predictions using a plausibly exogenous trade-induced labor market changes in Brazil. 



\section{Background and Data}

\subsection{Child Labor and School Attendance in Brazil}

Brazil has been successful in adopting policies in order to eliminate child labor, however the number of working children is still high, specially in lower socioeconomic groups (Barros e Mendonça (2010)). According to Brazilian Demographic Census, in 1991 there were almost 1.5 million children aged 10-14 years working. In 2010, the occurrence of child labor declined by almost $27 \%$ to over than 1 million children, which represented $7.6 \%$ of the Brazilian children between 10 and 14 years old. Among the working children in 2010, 55\% were in the urban area and $45 \%$ in the rural area. Although the share of working children in the rural area was lower than in the urban region, $12.7 \%$ of the children living in rural areas were in the labor force, against only $5.1 \%$ of the urban children.

Despite the improvement in socioeconomic conditions of Brazilian families in the last decades, Barros e Mendonça (2010) argue that specific policies in order to eradicate child labor in Brazil were the most important factor in reducing the number of working children. In 1998, for example, the constitutional amendment n 20 changed to 16 the minimum age at which a child can enter the labor market, except in the case of activities exercised as an apprentice, which can be practiced from the age of 14 . In 2000, the federal government created the cash transfer program Eradication of Child Labor (Programa de Erradicação do Trabalho Infantil - Peti) and in the same period, the country ratified two international conventions of the International Labor Organization: Convention 182, which deals with the prohibition of the worst forms of child labor and Convention 138, which establishes some norms to curb child labor.

However, child labor is still a relevant problem and it has admittedly various perverse effects on the development of children. Among the most worrying concerns are the late entry in school, the school dropout and the illness contracted due to the work. Regarding school attainment, despite the efforts over the 2000s to improve the primary school access, the data shows that Brazil did not achieve the goal of universal access. In 2010, 3,3\% of children between 10 and 14 years old were out of school; among the working children, this share was $10.5 \%$. 


\subsection{China Trade Shock}

The China's rapid growth and increased openness over the past three decades is one of the most important economic phenomena in recent years, as it opened the country's market for more international trade and investment and leads China to the top traders in the world ${ }^{1}$. This extraordinary increase in its international trade participation had a large impact on world economy and has been widely studied by economists. On the one hand the growth of the Chinese manufacturing sector has caused concerns all over the world about competition with locally produced goods. On the other hand, the increase of the Chinese demand, especially for agricultural and extractive goods, exerted a positive impact on exports from developing countries.

Specifically for Brazil, while exports to China were increasingly concentrated in primary products, the imports were accounted for diversified manufacturing appliances. Regardless of this pattern, the importance of China in both the Brazilian imports and exports has risen steeply in recent years. In 2010 China was Brazil's largest trading partner, accounting for over $16.0 \%$ of total Brazilian exports and supplying over $14.0 \%$ of its imports (in 2000, these shares were approximately $2.0 \%$ ). While free trade generally results in gains in aggregate welfare, the distribution of these gains is uneven across regions and segments of the population within a country, as showed by Costa, Garred e Pessoa (2016). Exploring the "China trade shock", the authors find that Brazilian local labor markets most affected by Chinese import competition experienced slower growth in manufacturing wages, while locations benefiting from rising Chinese commodity demand registered faster wage growth and shifts in the local economy towards formal jobs.

Given the extraordinary relevance in terms of magnitude, the Chinese trade shock is an excellent setting to study the relationship between international trade, child labor and schooling in Brazil. First, the trade shocks from rising manufacturing competition and export demand are plausibly exogenous, which support a causal interpretation when combined with the instrumental variables approach proposed by Costa, Garred e Pessoa (2016) and used in this

$1 \quad$ China was the world's largest exporter of goods and the second largest importer in 2015, accounting for almost $14.0 \%$ of total exports and $10 \%$ of total imports according to World Trade Organization (2016). 
paper. Second, the asymmetric effect that China's export and import growth has had on local labor markets in Brazil gives a great opportunity to exploit distinctly exogenous changes to the returns to adult labor as well as returns to the child labor, offering an interesting strategy to better understanding the operation of income and substitution effects.

\subsection{Data and Summary Statistics}

In order to empirically develop my exercise, I use data from Brazilian Demographic Census (Censo Demográfico) for 2000 and 2010, administered by Brazil's census bureau (Instituto Brasileiro de Geografia e Estatística - IBGE). Since official statistics for the Census employment section are collected only for people aged 10 and older and 14 is typically the minimum age ${ }^{2}$ acceptable for child employment according to International Labor Organization ${ }^{3}$, the sample includes children aged 10 to 14, and a child worker is anyone aged 14 or younger who was employed in the survey reference week, including in activities for household members for sustenance or without payment. A child attends school if he/she reports it in the survey regardless if he/she works or not. I also consider several other measures of children activities according to child status. Therefore, a child is labeled working full-time if he/she works but does not attend school; working part-time if he/she works and attends school; attend school full-time if he/she attends school but does not work, and idle if he/she does not work and does not attend school.

The empirical analysis is conducted at the microregion level, constructed by IBGE (2002) as a group of contiguous municipalities (counties), in the same state, with similar geographic and productive characteristics, closely to a notion of a local labor market. Since there were changes in municipalities boundaries over time, I use the definition of microregions from Reis, Pimentel e Alvarenga (2007), which harmonize the political-administrative divisions in the various census. The sample includes 413 microregions.

Table 1 provides descriptive statistics on schooling and child labor between 1980 and 2010 for Brazil. Each cell contains the participation share in the indicated activity for children

2 As discussed in the previous section, the minimum age to work in Brazil is 16, but activities exercised as an apprentice can be legally practiced from the age of 14 .

3 See International Labor Organization (1973) 
Table 1 - Summary statistics - Children activities

\begin{tabular}{|c|c|c|c|c|}
\hline & 1980 & 1991 & 2000 & 2010 \\
\hline & (1) & $(2)$ & $(3)$ & (4) \\
\hline \multirow[t]{2}{*}{ Children population } & 34,596 & 41,281 & 42,019 & 41,567 \\
\hline & $(78,585)$ & $(94,365)$ & $(93,798)$ & $(94,120)$ \\
\hline \multirow[t]{2}{*}{ Attend school } & 0.622 & 0.750 & 0.936 & 0.967 \\
\hline & $(0.152)$ & $(0.109)$ & $(0.038)$ & $(0.017)$ \\
\hline \multirow[t]{2}{*}{ Attend school only } & 0.574 & 0.702 & 0.862 & 0.897 \\
\hline & $(0.145)$ & $(0.108)$ & $(0.064)$ & $(0.046)$ \\
\hline \multirow[t]{2}{*}{ Work } & 0.153 & 0.111 & 0.088 & 0.076 \\
\hline & $(0.064)$ & $(0.049)$ & $(0.052)$ & $(0.040)$ \\
\hline \multirow[t]{2}{*}{ Work only } & 0.105 & 0.064 & 0.014 & 0.007 \\
\hline & $(0.050)$ & $(0.033)$ & $(0.011)$ & $(0.004)$ \\
\hline \multirow[t]{2}{*}{ Work and study } & 0.048 & 0.048 & 0.074 & 0.070 \\
\hline & $(0.029)$ & $(0.025)$ & $(0.045)$ & $(0.039)$ \\
\hline \multirow[t]{2}{*}{ Idle } & 0.272 & 0.186 & 0.050 & 0.027 \\
\hline & $(0.126)$ & $(0.095)$ & $(0.032)$ & $(0.014)$ \\
\hline Obs & 412 & 413 & 413 & 413 \\
\hline
\end{tabular}

This table provides summary statistics for the main variables of interest. Each cell contains the participation share in the indicated activity for children between 10 and 14 years old. Variables are measured at the microregion level. Standard deviations are in parentheses. Source: Brazilian Demographic Census.

between 10 and 14 years old. The focus of this paper is on the period between 2000 and 2010, the years in which China emerged as major player in international trade, but I included data from previous years to highlight the underlying time trends. School attendance rates has substantially increased over the decades. On average, over than $62.0 \%$ of the children between 10 and 14 years old attended school in 1980. By 2010, almost $97.0 \%$ attended school. This rise in school attendance is concomitant with a $93.3 \%$ decline in the fraction of children that are working without attending school. Despite the decline in the proportion of working children in this period, more children were working and studying in 2010 compared to $1980^{4}$.

In addition to information about children activities, I also use data from School Census for 2000 and 2010 and from National System for the Evaluation of Basic Education (Sistema Nacional de Avaliação da Educação Básica - Saeb) for 2001 and $2011^{5}$, both provided by National

4 Indeed, the majority of children that work in Brazil are also enrolled in school. On average, this group represented almost $90.0 \%$ of working children in 2010 and over $83.0 \%$ in 2000 .

5 The National System for the Evaluation of Basic Education, established in 1995, is a set of large-scale 
Institute of Educational Studies and Research Anísio Teixeira, to create measures of students performance and microregion school quantity/quality. Finally, the data on international trade in goods for 2000 and 2010 used in to build the trade shock measures is from U.N. Comtrade Database, which contains the total annual value of bilateral trade at the 6 -digit level of the Harmonized System classification for more than 200 countries. The data is denominated in 2010 US dollars and was deflated using the US GDP deflator from the US Bureau of Economic Analysis.

external evaluations (sample designed) held every two years whose main objective is to carry out a diagnosis of Brazilian basic education and some factors that may interfere with students performance, providing an indication of the quality of the offered education. The evaluation system was restructured in 2005 and started to be composed of two evaluations: the National Assessment of Basic Education (Aneb), which maintained the characteristics and procedures of Saeb, and the National Assessment of School Performance (Anresc), known as Prova Brasil, created with the objective of evaluating the quality of education in all public schools (Census design). 



\section{Empirical Strategy}

\subsection{Measuring Trade Shocks}

Following Costa, Garred e Pessoa (2016), my identification strategy exploits the asymmetric effect that China's export and import growth has had on local labor markets in Brazil. Hence, I build a region-specific indicator for the exposure to Chinese trade shocks as follows:

$$
\begin{aligned}
X D_{m} & \equiv \sum_{j} \frac{L_{m j, 2000}}{L_{j, 2000}} \frac{\Delta X_{j}}{L_{m, 2000}} \\
I S_{m} & \equiv \sum_{j} \frac{L_{m j, 2000}}{L_{j, 2000}} \frac{\Delta I_{j}}{L_{m, 2000}}
\end{aligned}
$$

where $\Delta X_{j}\left(\Delta I_{j}\right)$ represents the difference in the value of Brazilian exports (imports) to (from) China in sector $j$ between 2000 and 2010 denominated in thousands of 2010 US dollars. The variable $L_{m j, 2000}$ is the size of workforce in sector $j$ within microregion $m$ in 2000, while $L_{j, 2000}$ and $L_{m, 2000}$ are the Brazilian workforce in sector $j$ and in microregion $m$, respectively. Therefore, the measure of the microregion shock is the weighted average of the change in imports and exports per worker across industries, where the weights capture the relative importance of each industry in a given region at the pre-shock period ${ }^{1}$.

The basic intuition is that different microregions have been more or less exposed to the rise of China as a major player in international trade depending on their pre-shock industry specialization. In particular, the Chinese shock has been stronger in those microregions in which larger share of workers was employed in industries that subsequently registered a higher growth in exports (imports) to (from) China. The most exposed Brazilian regions to Chinese demand shocks were those specialized in agricultural or extractive sectors, specially soybeans, mining of nonprecious metals (iron ore) and oil and gas. Together, this three sectors were responsible for $82 \%$ of the growth in Brazil's exports to China between 2000 and 2010, as can be seen in Table B1. On the other hand, the regions specialized in manufacturing production were the most

$\overline{1}$ Following Costa, Garred e Pessoa (2016), for the top and bottom $1 \%$ of the $I S_{m}$ and $X D_{m}$ distribution, I assign, respectively, the values of the 99 th and 1st percentiles in order to prevent empirical results being affected by outliers. 
affected by the China supply shocks. Electronics, machinery and electrical equipment accounted for approximately $43 \%$ of the total growth in Brazil's imports from China between 2000 and 2010.

The measures $I S_{m}$ and $X D_{m}$ capture the overall trade exposure experienced by microregions, but does not distinguish between employment shocks that differentially affect adult and child workers. Hence, to account for the fact that sectors differ in their adult and child employment intensity, I modify Equation (4.1) to construct disaggregated trade shock measures that exploit the spatial distribution of children across microregions and sectors. The main intuition is the same as before, but now trade shocks of a given magnitude will differentially affect adult and child depending on the set of sectors that is exposed, capturing the great heterogeneity that exists across Brazilian microregions. Basically, the new measure consists in using a new set of weights that captures the share of working children/adults in a specific sector in a given microregion:

$$
\begin{array}{rlrl}
X D_{m}^{\text {Child }} & \equiv \sum_{j} \frac{L_{m j, 2000}^{\text {Child }}}{L_{j, 2000}^{C h i l d}} \frac{\Delta X_{j}}{L_{m, 2000}} & X D_{m}^{\text {Adult }} \equiv \sum_{j} \frac{L_{m j, 2000}^{\text {Adult }}}{L_{j, 2000}^{\text {Adult }}} \frac{\Delta X_{j}}{L_{m, 2000}} \\
I S_{m}^{\text {Child }} & \equiv \sum_{j} \frac{L_{m j, 2000}^{\text {Child }}}{L_{j, 2000}^{C h i l d}} \frac{\Delta I_{j}}{L_{m, 2000}} & I S_{m}^{\text {Adult }} & \equiv \sum_{j} \frac{L_{m j, 2000}^{\text {Adult }}}{L_{j, 2000}^{\text {Adult }}} \frac{\Delta I_{j}}{L_{m, 2000}}
\end{array}
$$

Table 2 shows that the average overall import and export exposure was, respectively, US\$ 236.30 and US\$ 431.97 per worker. The average import competition shock concentrated on adult exposure was US\$235.29 per worker, and that concentrated on child exposure was US\$ 347.47 per worker. The respectively averages for export exposures were US\$433.48 and US $\$ 179.04$ per worker. On average, children corresponded to $2.2 \%$ of the total workforce and were mainly employed in agricultural activities, as can be seen in Table B1. Note that both aggregated and disaggregated measures have large standard deviations, which reflect the great heterogeneity of exposure across microregions. Furthermore, the maps in Figure 1 suggest that the incidence of Chinese trade shocks is relatively widely distributed across Brazil.

The advantage of this strategy is that it provides a good proxy for distinctly exogenous changes to the returns to adult labor as well as returns to the child labor, since it exploits 
Table 2 - Summary statistics - Chinese trade shock measures (overall and age-specific exposure)

\begin{tabular}{|c|c|c|c|c|c|c|}
\hline & Obs & Mean & Std. Dev. & 25 th & Median & 75 th \\
\hline \multicolumn{7}{|l|}{ I. Overall shocks } \\
\hline Import supply shock & 413 & 236.30 & 275.11 & 78.12 & 133.79 & 268.51 \\
\hline Export demand shock & 413 & 431.97 & 742.34 & 54.46 & 162.35 & 423.83 \\
\hline \multicolumn{7}{|c|}{ II. Adult exposure shocks } \\
\hline Import supply shock & 413 & 235.29 & 275.88 & 77.14 & 132.93 & 268.81 \\
\hline Export demand shock & 413 & 433.48 & 745.02 & 54.62 & 165.07 & 430.20 \\
\hline \multicolumn{7}{|c|}{ III. Child exposure shocks } \\
\hline Import supply shock & 413 & 347.47 & 477.68 & 61.15 & 187.80 & 422.84 \\
\hline Export demand shock & 413 & 179.04 & 420.33 & 6.99 & 36.00 & 155.88 \\
\hline
\end{tabular}

This table provides summary statistics for the export and import exposure measures reported in 2010 U.S. dollars per worker, averaged at the microregion level. Panel I displays the overall shocks calculated using equation (4.1), while panels II and III display disaggregated trade shocks according to adult and child labor exposure defined by equation (4.2).

trade-induced labor market changes that only shifts the return to one but not to the other group depending on the set of industries that are exposed (some sectors employ more or less children than others). Furthermore, this approach also exploits the geographical distribution of child labor, capturing the great heterogeneity that exists across Brazilian microregions. Most closely related to the present paper is a recent work by Bai (2016), who exploits 1991 Indian tariff reform to examine the impact of losing tariff protection on children activities. To my knowledge, the author is the first one to propose a strategy to identify income and substitution effects computing disaggregated tariff measures according to adult and child labor-intensive sectors. The advantage of my strategy, however, is that it captures a directly children exposure to trade shock since it takes into account the geographical distribution of working children across Brazilian microregions. This is possible because data from Brazilian Demographic Census allows me to exploit the spatial distribution of children across microregions and sectors, which is a better approach to identify the labor market shocks that directly affect children.

To identify the most and the least child labor-intensive crops, Bai (2016) measures the child labor intensity for a given crop as the percentage of child work, averaged across all 
households growing that crop in the survey sample. However, some crops are grown by just a few households, which is a problem since the measures can be hardly influenced by households that intensively employ children in certain types of crops. To deal with this problem, the author aggregates the crops into broad categories and run a fixed effects regression choosing the child labor intensive sectors according to the estimates. Once defined the child labor-intensive crops, Bai (2016) constructs district tariff measures using an analogous shift-share strategy employed in this paper. The problem with her strategy is that the results are sensitive to the choice of the omitted category and her average agricultural tariff measure attributable to child (adult) labor intensive-crops is totally based on this definition. My strategy is similar to hers in the sense that it also considers the differences in the industries' adult and child employment intensities, but my disaggregated measures of exposure to the trade shock is a portion of the overall shock depending on the share of child and adult workers in a specific sector in a given microregion. This is a better approach to identify the shocks that directly affect children because it captures the real children exposure to that shock in each particular sector.

\subsection{Empirical Framework}

Brazilian microregions differ in their exposure to the China trade shock based on their pre-shock industry composition. Therefore, to assess the causal effects of trade exposure on child labor and schooling, I adopt the following baseline specification:

$$
\Delta y_{m}=\beta_{0}+\beta_{1} X D_{m}+\beta_{2} I S_{m}+W_{m}^{\prime} \gamma+\epsilon_{m}
$$

where the outcomes of interest are: i) the employment status, measured as the difference between 2000 and 2010 in the share of children employed (Work), employed and not studying (Work only), and employed and studying (Work and study); and ii) the educational attendance, measured as difference between 2000 and 2010 in the share of children that attend school. Following Costa, Garred e Pessoa (2016), in all regressions I include a set of controls $\left(W_{m}^{\prime}\right)$ that includes the size of the local workforce, the share of employed in informal jobs, the proportion of rural residents, 
the share of each microregion's workforce employed in agricultural sectors, extractive sectors and manufacturing sectors in 2000. I also control for 2000 microregion demographic characteristics that might affect child labor and schooling such as the average household income, the average number of people living in the household, the percentage of a microregion's population that is nonwhite, the population shares that are female and college-educated, and the percentage of a microregion's population in 6 age groups. I also include state fixed effects for Brazil's 26 states and one federal district to capture any particular structural changes that affect all the microregions in the same state. Finally, in all regressions I cluster standard errors at the level of the mesoregion ${ }^{2}$ in order to allow spatial correlation of errors across microregions and weight the regressions by the initial share of the national children population.

An issue to the empirical approach is the possible endogeneity of the trade shock. In particular, the regression (4.3) may not capture the causal effects of the China shocks on child labor and schooling in the presence of shocks there are both correlated to the dependent variables and to the trade exposure measures $\left(I S_{m}\right.$ and $\left.X D_{m}\right)$. This poses a problem, because changes in domestic productivity in specific sectors in which Brazil also experienced a large change in trade with China, for example, could simultaneously affect local trade exposure, local labor market conditions, and local children activities. Alternatively, changes in world prices or quantities traded that are not due to China, but to a worldwide supply or demand shock may explain the pattern observed in the trade between Brazil and China, since it will impact the trade flows of all countries. Therefore, to identify the causal effect of rising Chinese trade exposure on local-level human capital adjustments outcomes, I follow Costa, Garred e Pessoa (2016) and employ an instrumental-variables strategy that uses information on growth in trade between China and countries other than Brazil to deal with local sectoral specific shocks. Furthermore, the strategy also deals with possible correlated changes in prices and quantities at the global level.

In particular, the strategy consists of using a fixed-effect regression to estimate the net contribution of China to the world sectoral import and export growth rates between 2000 and

2 Mesoregion is a group of contiguous microregions, in the same state, with similar market characteristics. The sample includes 91 mesoregions whose boundaries are consistent over time. 
2010 and then take the product of these estimate fixed effects and the initial trade levels between Brazil and China. Specifically, I first define $\frac{\Delta \tilde{I}_{i j}}{\tilde{I}_{i j, 2000}}$ and $\frac{\Delta \tilde{X}_{i j}}{\tilde{X}_{i j, 2000}}$ as the growth rate of the total imports (exports) of country $i$ in sector $j$ between 2000 and 2010 from (to) all countries other than Brazil. Then, I run the following regressions using data for all countries available in the U.N. Comtrade dataset, except Brazil. The regressions are weighted by 2000 import (export) volumes:

$$
\begin{gathered}
\frac{\Delta \tilde{I}_{i j}}{\tilde{I}_{i j, 2000}}=\alpha_{j}+\psi_{j}^{\text {China }}+\epsilon_{i j} \\
\frac{\Delta \tilde{X}_{i j}}{\tilde{X}_{i j, 2000}}=\gamma_{j}+\delta_{j}^{C h i n a}+\mu_{i j}
\end{gathered}
$$

The world-level shocks are captured by the sector fixed effects, $\alpha_{j}$ and $\gamma_{j}$, which represent, respectively, the mean growth rate of imports and exports across countries net of Brazil. The China-specific dummies, $\psi_{j}^{\text {China }}$ and $\delta_{j}^{\text {China }}$ capture the deviation in the growth rate of China's imports and exports in sector $j$ excluding trade with Brazil. Next, I multiply these estimates by the values of Brazil-China imports and exports in 2000 , defining ${ }^{3} \Delta \tilde{I}_{j} \equiv I_{j, 2000} \hat{\delta}_{j}^{C h i n a}$ and $\Delta \tilde{X}_{j} \equiv X_{j, 2000} \hat{\psi}_{j}^{\text {China }}$. Hence, the instrumental variables ${ }^{4}$ are constructed in the same way as in Equation (4.1):

$$
\begin{aligned}
i v X D_{m} & \equiv \sum_{j} \frac{L_{m j, 2000}}{L_{j, 2000}} \frac{\Delta \tilde{X}_{j}}{L_{m, 2000}} \\
i v I S_{m} & \equiv \sum_{j} \frac{L_{m j, 2000}}{L_{j, 2000}} \frac{\Delta \tilde{I}_{j}}{L_{m, 2000}}
\end{aligned}
$$

3 Note that $\hat{\psi}_{j}^{\text {China }}$ identifies the growth rate of China's imports and thus it is related to the export-side shock for Brazil, while $\hat{\delta}_{j}^{\text {China }}$, which identifies the growth rate of China's export, is related to the import-side shock for Brazil.

4 The instrumental variables disaggregated by child (adult) labor-intensive sectors are constructed using the same methodology and the Equation (4.2). 


\section{Main Results}

\subsection{Impact of Trade Shock on Children Activities}

As primary evidence of the effects of China trade shocks on child labor and school attendance, Table 3 displays the results of the regressions, as specified by Equation (4.3), of the changes in the share of children employed and in the share of children that attend school between 2000 and 2010. The outcomes are multiplied by 100, so that the estimates may be interpreted as the effect of a US $\$ 1000$ increase in imports and exports per worker on changes in the dependent variables in percentage points. Columns (1) and (3) show the coefficients from the OLS estimation, while columns (2) and (4) present the IV estimates ${ }^{1}$, which are the main specifications of the paper.

The results suggest an asymmetric child labor and schooling impacts that depend upon the source of the shock. First, both the OLS and the IV estimates suggest that larger overall import competition shocks (i.e., not distinguishing between age components) are associated with lower school attendance over these ten years. The estimates in column (2) of Panel I indicates that a US\$ 1000 per worker increase in import competition from China reduces the share of children that attend school by 1.41 percentage points. This implies that one standard deviation of Chinese import competition led to a decline of 0.14 standard deviation in school attendance over the decade.

However, Panel II of Table 3 reveals that shocks to adult and child-intensive employment have opposite signed effects on school attendance. Conditional on child labor market shocks, larger import competition shocks concentrated on adult decrease the share of children that attend school, while conditional on adult labor market shocks, an adverse shock concentrated on children has a positive effect on schooling, but the estimates are not statistically significant. Table 3 also reports the results for child labor. As can be seen in Panel I, the overall export demand shock has no effect on the share of children that work, but point estimates in columns (3) and (4) display a negative relationship between import competition shock and child labor.

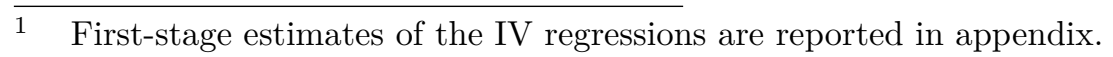


Table 3 - Main results - The effects of trade shocks on school attendance and child labor

\begin{tabular}{|c|c|c|c|c|}
\hline \multirow[t]{3}{*}{ Dependent Variable } & \multicolumn{2}{|c|}{ Attend school } & \multicolumn{2}{|c|}{ Work } \\
\hline & OLS & IV & OLS & IV \\
\hline & (1) & $(2)$ & $(3)$ & $(4)$ \\
\hline \multicolumn{5}{|l|}{ I. Overall Trade Shocks } \\
\hline Import Competition $\left(I S_{m}\right)$ & $\begin{array}{c}-1.323^{*} \\
(0.752)\end{array}$ & $\begin{array}{c}-1.408^{*} \\
(0.796)\end{array}$ & $\begin{array}{c}-1.421^{* * *} \\
(0.287)\end{array}$ & $\begin{array}{c}-1.367^{* * *} \\
(0.255)\end{array}$ \\
\hline Export Demand $\left(X D_{m}\right)$ & $\begin{array}{c}-0.299^{* *} \\
(0.118)\end{array}$ & $\begin{array}{c}-0.224^{*} \\
(0.124)\end{array}$ & $\begin{array}{c}0.093 \\
(0.142)\end{array}$ & $\begin{array}{c}0.033 \\
(0.124)\end{array}$ \\
\hline \multicolumn{5}{|l|}{ II. Disaggregated Trade Shocks } \\
\hline Import Competition Concentrated on Adult & $\begin{array}{c}-1.342^{*} \\
(0.725)\end{array}$ & $\begin{array}{c}-1.483^{*} \\
(0.808)\end{array}$ & $\begin{array}{c}-1.301^{* * *} \\
(0.296)\end{array}$ & $\begin{array}{c}-1.131^{* * *} \\
(0.287)\end{array}$ \\
\hline Import Competition Concentrated on Child & $\begin{array}{c}0.107 \\
(0.118)\end{array}$ & $\begin{array}{c}0.189 \\
(0.144)\end{array}$ & $\begin{array}{c}-0.221^{* *} \\
(0.099)\end{array}$ & $\begin{array}{c}-0.232^{* *} \\
(0.108)\end{array}$ \\
\hline Export Demand Concentrated on Adult & $\begin{array}{c}-0.238^{*} \\
(0.122)\end{array}$ & $\begin{array}{c}-0.210^{*} \\
(0.123)\end{array}$ & $\begin{array}{c}0.098 \\
(0.158)\end{array}$ & $\begin{array}{c}0.138 \\
(0.154)\end{array}$ \\
\hline Export Demand Concentrated on Child & $\begin{array}{l}-0.302 \\
(0.227)\end{array}$ & $\begin{array}{l}-0.107 \\
(0.251)\end{array}$ & $\begin{array}{l}-0.035 \\
(0.362)\end{array}$ & $\begin{array}{c}-0.733^{* * *} \\
(0.260)\end{array}$ \\
\hline Observations & 413 & 413 & 413 & 413 \\
\hline
\end{tabular}

This table displays estimated effects of Chinese import and export shocks on changes between 2000 and 2010 in child labor and school attendance. Dependent variable in columns (1) and (2) is the share of children that attend school, while columns (3) and (4) refer to the percentage of children that work. Panel I displays the results for the aggregated shock measures, while Panel II shows the results for the disaggregated measures. All regressions include a constant and the following controls: 2000 workforce, 2000 share of workforce in agricultural sectors, 2000 share of workforce in extractive sectors, 2000 share of workforce in manufacturing, 2000 share of workforce in informal jobs, 2000 share of workforce in rural areas and microregion-level demographic controls such as the 2000 average household income, the 2000 average number of people living in the household, the 2000 percentage of a microregion's population that is nonwhite, the 2000 share of population that are female and college-educated, and the 2000 percentage of a microregion's population in 6 age groups. Regressions are weighted by the share of national children population in 2000 . Standard errors are clustered by mesoregion, 91 clusters. ${ }^{*} p<0.1,{ }^{* *}$ $p<0.05,{ }^{* * *} p<0.01$

The same pattern is seen in Panel II, which shows that both adverse shocks on adults and on children decrease the share of working children.

To better understand these patterns, Table 4 tightens the focus to different measures of children activities. Panel I shows that the overall import competition shock associated with a decrease in the share of children that work and attend school. The estimates in column (6) indicate that a US\$ 1000 per worker increase in import competition from China reduces the share of children that work and study part-time by 1.36 percentage points. There is no evidence that the adverse overall import competition shock affected the share of children that study full-time or work full-time. Although, the shock increases the share of children that do not 
report work as a principal activity and also do not attend school, i.e., the share of idle children. According to the point estimates in column (8), a US\$ 1000 per worker increase in import competition from China increases the share of idle children by 1.41 percentage points. Panel II reveals that this effect is entirely driven by adult exposure to import competition shock.

As discussed by Edmonds, Pavcnik e Topalova (2010), there are two possible explanations for the increased presence of idle children in microregions most exposed to Chinese import competition shock. First, it might reflects mismeasurement of child activities, since some parents may not report that their children are involved in working activities. Second, in the presence of constraints on the availability of wage employment for children, for example, it can be optimal not to allocate children to working activities. On the other hand, Edmonds, Pavcnik e Topalova (2010) show that declines in schooling are largely driven by the avoidance of direct and indirect costs of schooling. Due to limited data, I can not use the methodology of the paper to estimate a similar relationship between trade integration and household schooling expenditures, but a qualitative description using data from Household Budget Research for 2007-2008 (Pesquisa de Orçamentos Familiares - POF) administered by IBGE, shows that the share of education in the budget of the poorest households is $0.9 \%$ and $2.9 \%$ in the richest ones. This pattern suggests that schooling expenditures are positive correlated to income and adverse income shocks can affect school attendance through schooling costs. A third mechanism that can explain why children dropout labor market even when adults are exposed to adverse shocks is the changes in the composition of local employment across sectors in response to trade shocks. I explore this mechanism in the next section.

Panel II of Table 4 shows that shocks to child-intensive employment have a negative effect on the share of children that work and study. According to the point estimates of column (6), the average import trade shock on child labor-intensive sectors (US\$ 347.47) is associated with a 0.06 percentage points decline in the share of children that attend school and work part-time between 2000 and 2010. There is no evidence that the import competition shock affects the share of idle children or those that work full-time. Although, the import trade shock on children increases the share of children that attend school full-time, as can be seen in columns (1) and (2). On the other hand, there is no robust evidence that disaggregated export demand 
Table 4 - Main results - The effects of trade shocks on children activities

\begin{tabular}{|c|c|c|c|c|c|c|c|c|}
\hline \multirow[t]{3}{*}{ Dependent Variable } & \multicolumn{2}{|c|}{ Attend school only } & \multicolumn{2}{|c|}{ Work only } & \multicolumn{2}{|c|}{ Work and study } & \multicolumn{2}{|c|}{ Idle } \\
\hline & OLS & IV & OLS & IV & OLS & IV & OLS & IV \\
\hline & (1) & $(2)$ & $(3)$ & (4) & (5) & (6) & (7) & (8) \\
\hline \multicolumn{9}{|l|}{ I. Overall Trade Shocks } \\
\hline Import Competition $\left(I S_{m}\right)$ & $\begin{array}{c}0.083 \\
(0.771)\end{array}$ & $\begin{array}{c}-0.048 \\
(0.796)\end{array}$ & $\begin{array}{l}-0.014 \\
(0.114)\end{array}$ & $\begin{array}{c}-0.007 \\
(0.113)\end{array}$ & $\begin{array}{c}-1.407^{* * *} \\
(0.294)\end{array}$ & $\begin{array}{c}-1.360^{* * *} \\
(0.270)\end{array}$ & $\begin{array}{l}1.337^{*} \\
(0.681)\end{array}$ & $\begin{array}{c}1.415^{* *} \\
(0.719)\end{array}$ \\
\hline Export Demand $\left(X D_{m}\right)$ & $\begin{array}{c}-0.284 \\
(0.177)\end{array}$ & $\begin{array}{c}-0.152 \\
(0.169)\end{array}$ & $\begin{array}{c}0.108^{*} \\
(0.055)\end{array}$ & $\begin{array}{c}0.105^{*} \\
(0.058)\end{array}$ & $\begin{array}{l}-0.015 \\
(0.120)\end{array}$ & $\begin{array}{c}-0.072 \\
(0.108)\end{array}$ & $\begin{array}{c}0.191^{* *} \\
(0.077)\end{array}$ & $\begin{array}{c}0.119 \\
(0.082)\end{array}$ \\
\hline \multicolumn{9}{|l|}{ II. Disaggregated Trade Shocks } \\
\hline Import Competition Concentrated on Adult & $\begin{array}{l}-0.028 \\
(0.753)\end{array}$ & $\begin{array}{l}-0.317 \\
(0.874)\end{array}$ & $\begin{array}{c}0.013 \\
(0.115)\end{array}$ & $\begin{array}{c}0.036 \\
(0.123)\end{array}$ & $\begin{array}{c}-1.314^{* * *} \\
(0.302)\end{array}$ & $\begin{array}{c}-1.166^{* * *} \\
(0.281)\end{array}$ & $\begin{array}{c}1.329^{* *} \\
(0.660)\end{array}$ & $\begin{array}{c}1.447^{* *} \\
(0.721)\end{array}$ \\
\hline Import Competition Concentrated on Child & $\begin{array}{l}0.266^{*} \\
(0.134)\end{array}$ & $\begin{array}{c}0.362^{* *} \\
(0.171)\end{array}$ & $\begin{array}{l}-0.062 \\
(0.041)\end{array}$ & $\begin{array}{l}-0.059 \\
(0.037)\end{array}$ & $\begin{array}{c}-0.159^{*} \\
(0.092)\end{array}$ & $\begin{array}{c}-0.173^{*} \\
(0.101)\end{array}$ & $\begin{array}{l}-0.045 \\
(0.114)\end{array}$ & $\begin{array}{c}-0.129 \\
(0.134)\end{array}$ \\
\hline Export Demand Concentrated on Adult & $\begin{array}{l}-0.236 \\
(0.190)\end{array}$ & $\begin{array}{l}-0.232 \\
(0.196)\end{array}$ & $\begin{array}{l}0.100^{*} \\
(0.054)\end{array}$ & $\begin{array}{c}0.117^{* *} \\
(0.059)\end{array}$ & $\begin{array}{l}-0.002 \\
(0.137)\end{array}$ & $\begin{array}{c}0.022 \\
(0.133)\end{array}$ & $\begin{array}{c}0.137 \\
(0.083)\end{array}$ & $\begin{array}{c}0.093 \\
(0.078)\end{array}$ \\
\hline Export Demand Concentrated on Child & $\begin{array}{c}-0.234 \\
(0.430)\end{array}$ & $\begin{array}{l}0.546^{*} \\
(0.309)\end{array}$ & $\begin{array}{c}0.033 \\
(0.074)\end{array}$ & $\begin{array}{c}-0.079 \\
(0.082)\end{array}$ & $\begin{array}{c}-0.068 \\
(0.346)\end{array}$ & $\begin{array}{c}-0.653^{* *} \\
(0.294)\end{array}$ & $\begin{array}{c}0.269 \\
(0.178)\end{array}$ & $\begin{array}{c}0.186 \\
(0.206)\end{array}$ \\
\hline Observations & 413 & 413 & 413 & 413 & 413 & 413 & 413 & 413 \\
\hline $\begin{array}{l}\text { This table displays estimated effects of Chinese impor } \\
\text { children that attend school full-time, the share of child } \\
\text { that does not work and does not attend school (idle). } \\
\text { measures. All regressions include a constant and the fol } \\
\text { sectors, } 2000 \text { share of workforce in manufacturing, } 20 \\
\text { controls such as the } 2000 \text { average household income, tl } \\
\text { nonwhite, the } 2000 \text { share of population that are fema } \\
\text { weighted by the share of national children population }\end{array}$ & $\begin{array}{l}\text { nd exl } \\
\text { that } \\
\text { nel I di } \\
\text { ving co } \\
\text { share } \\
2000 \text { a }\end{array}$ & $\begin{array}{l}\text { ocks on } \\
\text { all-time, } \\
\text { the resu } \\
2000 \text { wo } \\
\text { kforce i } \\
\text { number }\end{array}$ & $\begin{array}{l}\text { s betwe } \\
\text { are of c } \\
\text { he agg } \\
2000 \\
\text { nal job }\end{array}$ & $\begin{array}{l}0 \text { and } \\
n \text { that } \\
\text { shock } \\
\text { of workf } \\
0 \text { share }\end{array}$ & $\begin{array}{l}\text { children } \\
\text { d attend } \\
\text { res, while } \\
\text { agricultur } \\
\text { kforce in }\end{array}$ & $\begin{array}{l}\text { es. Depee } \\
\text { part-time } \\
\text { I shows t } \\
\text { ors, } 2000 \\
\text { reas and }\end{array}$ & $\begin{array}{l}\text { ariables } \\
\text { le perce } \\
\text { lts for t } \\
\text { f workf } \\
\text { gion-le }\end{array}$ & $\begin{array}{l}\text { he share of } \\
\text { of children } \\
\text { aggregated } \\
\text { extractive } \\
\text { mographic } \\
\text { tion that is }\end{array}$ \\
\hline
\end{tabular}

shocks affected any children activity. Hence, the results show that when children are exposed to import competition shock, the most affected group is the one in which children divide their time working and studying. These basic results hold even when I control for pre-sample period trends or compute alternative trade shock measures. The robustness check is presented in Appendix A. As a consequence of the exposure, children work less, but keeping studying. Can this pattern bring benefits to the children in terms of school performance? The next section examines some school performance indicators in order to answer this question.

\subsection{Impact of Trade Shock on School Outcomes}

Having examined the impact of the Chinese trade shocks on children activities, I now attempt to further understand children's response to the shocks by considering their effects on other outcomes related to school performance. The basic intuition is that if children in regions most exposed to import competition shocks are working less and attending school full-time, it might be possible that they have a better performance in school. To test this hypothesis, I use data from National System for the Evaluation of Basic Education (Sistema Nacional de Avaliação da Educação Básica - Saeb) for 2001 and 2011, provided by National Institute of 
Educational Studies and Research Anísio Teixeira, to create measures of students performance in mathematics and language (portuguese) skills in the end of the primary school. Before 2005, the assessment was sample designed, hence I do not have information for all Brazilian municipalities. Consequently, when I take means for the microregion level, I get a smaller sample with just 323 microregions. To assess the effects of trade shock exposure on school performance, I use Equation (4.3) and the outcomes of interest are differences in log averages of math and portuguese scores, so that the coefficients may be (approximately) interpreted as the effect of a US\$ 1000 increase in imports or exports per worker on $100 \mathrm{x}$ changes in the dependent variable in percentage points. Additionally, I also assess the effects of trade shock exposure on the share of children that reports doing math/portuguese homework in order to capture the dedication to studies.

Table 5 - Main results - The effects of trade shocks on school performance

\begin{tabular}{|c|c|c|c|c|c|c|c|c|}
\hline \multirow[t]{3}{*}{ Dependent Variable } & \multicolumn{2}{|c|}{ Math Score } & \multicolumn{2}{|c|}{$\begin{array}{l}\text { Portuguese } \\
\text { Score }\end{array}$} & \multicolumn{2}{|c|}{$\begin{array}{l}\text { Math } \\
\text { Homework }\end{array}$} & \multicolumn{2}{|c|}{$\begin{array}{l}\text { Portuguese } \\
\text { Homework }\end{array}$} \\
\hline & OLS & IV & OLS & IV & OLS & IV & OLS & IV \\
\hline & (1) & $(2)$ & (3) & (4) & $(5)$ & (6) & (7) & $(8)$ \\
\hline \multicolumn{9}{|l|}{ I. Overall Trade Shocks } \\
\hline Import Competition $\left(I S_{m}\right)$ & $\begin{array}{c}0.006 \\
(0.030)\end{array}$ & $\begin{array}{l}-0.010 \\
(0.033)\end{array}$ & $\begin{array}{c}0.006 \\
(0.034)\end{array}$ & $\begin{array}{l}-0.021 \\
(0.041)\end{array}$ & $\begin{array}{c}1.310 \\
(2.462)\end{array}$ & $\begin{array}{l}-2.593 \\
(2.572)\end{array}$ & $\begin{array}{c}2.880 \\
(2.821)\end{array}$ & $\begin{array}{l}-0.138 \\
(3.031)\end{array}$ \\
\hline Export Demand $\left(X D_{m}\right)$ & $\begin{array}{l}-0.004 \\
(0.007)\end{array}$ & $\begin{array}{l}-0.007 \\
(0.007)\end{array}$ & $\begin{array}{l}-0.001 \\
(0.007)\end{array}$ & $\begin{array}{l}-0.003 \\
(0.008)\end{array}$ & $\begin{array}{l}-0.226 \\
(0.727)\end{array}$ & $\begin{array}{l}-0.249 \\
(0.893)\end{array}$ & $\begin{array}{c}1.165 \\
(0.846)\end{array}$ & $\begin{array}{l}1.243 \\
(0.903)\end{array}$ \\
\hline \multicolumn{9}{|l|}{ II. Disaggregated Trade Shocks } \\
\hline Import Competition Concentrated on Adult & $\begin{array}{l}-0.008 \\
(0.024)\end{array}$ & $\begin{array}{l}-0.023 \\
(0.028)\end{array}$ & $\begin{array}{l}-0.001 \\
(0.031)\end{array}$ & $\begin{array}{l}-0.025 \\
(0.039)\end{array}$ & $\begin{array}{c}0.893 \\
(2.267)\end{array}$ & $\begin{array}{l}-2.940 \\
(2.579)\end{array}$ & $\begin{array}{c}1.202 \\
(2.399)\end{array}$ & $\begin{array}{l}-1.684 \\
(3.352)\end{array}$ \\
\hline Import Competition Concentrated on Child & $\begin{array}{l}0.025^{*} \\
(0.015)\end{array}$ & $\begin{array}{c}0.028^{* *} \\
(0.014)\end{array}$ & $\begin{array}{c}0.014 \\
(0.012)\end{array}$ & $\begin{array}{c}0.014 \\
(0.012)\end{array}$ & $\begin{array}{c}0.925 \\
(1.803)\end{array}$ & $\begin{array}{c}0.449 \\
(2.047)\end{array}$ & $\begin{array}{c}3.308 \\
(3.347)\end{array}$ & $\begin{array}{c}2.955 \\
(3.820)\end{array}$ \\
\hline Export Demand Concentrated on Adult & $\begin{array}{l}-0.004 \\
(0.008)\end{array}$ & $\begin{array}{l}-0.007 \\
(0.008)\end{array}$ & $\begin{array}{l}-0.000 \\
(0.007)\end{array}$ & $\begin{array}{l}-0.001 \\
(0.008)\end{array}$ & $\begin{array}{l}-0.159 \\
(0.777)\end{array}$ & $\begin{array}{c}-0.327 \\
(0.921)\end{array}$ & $\begin{array}{c}1.194 \\
(0.900)\end{array}$ & $\begin{array}{l}1.181 \\
(0.926)\end{array}$ \\
\hline Export Demand Concentrated on Child & $\begin{array}{l}-0.002 \\
(0.009)\end{array}$ & $\begin{array}{l}-0.012 \\
(0.012)\end{array}$ & $\begin{array}{l}-0.004 \\
(0.010)\end{array}$ & $\begin{array}{l}-0.016 \\
(0.010)\end{array}$ & $\begin{array}{c}-0.528 \\
(1.409)\end{array}$ & $\begin{array}{c}0.665 \\
(1.770)\end{array}$ & $\begin{array}{l}-0.607 \\
(1.602)\end{array}$ & $\begin{array}{c}0.033 \\
(1.961)\end{array}$ \\
\hline Observations & 323 & 323 & 323 & 323 & 323 & 323 & 323 & 323 \\
\hline $\begin{array}{l}\text { This table displays estimated effects of Chinese impor } \\
\text { scores in columns (1) to (4) are measured in log differ } \\
\text { children that do homework. Panel I displays the res } \\
\text { regressions include a constant and the following contr } \\
2000 \text { share of workforce in manufacturing, } 2000 \text { share } \\
\text { such as the } 2000 \text { average household income, the } 2000 \\
\text { nonwhite, the } 2000 \text { share of population that are fema } \\
2000 \text { number of schools per student and the } 2000 \text { stu } \\
\text { in } 2000 \text {. Standard errors are clustered by mesoregion }\end{array}$ & $\begin{array}{l}\text { id expo } \\
\text { e, while } \\
\text { for th } \\
2000 \mathrm{w} \\
\text { rorkfor }\end{array}$ & $\begin{array}{l}\text { ks on ch } \\
\text { Homew } \\
\text { sated sh } \\
2000 \\
\text { ormal j }\end{array}$ & $\begin{array}{l}\text { enasure } \\
\text { of work } \\
000 \text { sha }\end{array}$ & $\begin{array}{l}\text { and } 201 \\
\text { Homewo } \\
\text { Panel } \\
\text { agricul } \\
\text { rkforce } \\
\text { ehold, t } \\
\text { ide the }\end{array}$ & $\begin{array}{l}\text { school pe } \\
\text { columns } \\
\text { ows the } \\
\text { sectors, } \\
\text { ral areas }\end{array}$ & $\begin{array}{l}\text { ance inc } \\
\text { o (8) are } \\
\text { s for the } \\
\text { hare of } \\
\text { microreg } \\
\text { of a mi } \\
\text { expense }\end{array}$ & $\begin{array}{l}\text { rs. Mat } \\
\text { x chan } \\
\text { ggrega } \\
\text { orce in } \\
\text { vel den }\end{array}$ & $\begin{array}{l}\text { ortuguese } \\
\text { le share o } \\
\text { sures. Al } \\
\text { ve sectors } \\
\text { ic control } \\
\text { on that is } \\
\text { ation, the } \\
\text { population }\end{array}$ \\
\hline
\end{tabular}

Panel I of Table 5 shows that the overall import and export shocks have no effects on school performance. However, as predicted by previously results, the children exposure to import competition shocks has a positive effect on school performance, as can be seen in Panel II. According to the point estimates of column (2), the average import trade shock on child labor-intensive sectors is associated with a 0.97 percentage points increase in microregion's 
average math score between 2000 and 2010, but there is no evidence that the shock has positive effect on portuguese scores. I find that point estimates for language are nonsignificant and smaller in magnitude when compared to the coefficients for math. The results are consistent with previous work on the efficacy of other educational interventions. Fryer (2014) finds that the adoption of a bundle of best practices by low-performing public schools (such as better human capital and increased instructional time) can significantly increase student achievement in math but has little or no effect on language. Exploring variation in violence that occurs across time and space when gangs battle over territories, Monteiro e Rocha (2012) find that students' scores are lower in math, but the proficiency in language is not affected by the violence. On the other hand, Emerson, Ponczek e Souza (2017) finds negative and significant impacts of working while in school on the math and portuguese proficiency scores of children enrolled in Sao Paulo municipal schools.

If import competition shocks on children have a significant effect on learning, it would be useful to understand the study habits of the children. As a primary attempt to do it, I investigate homework habits and find that, everything else equals constant, the same shock is associated with an increase in the share of children that reports doing math and portuguese homework, but the estimates are not statistically significant, as shown by the point estimates of columns (5) to (8). The child labor research has mainly focused on the trade-off between time spent at school and working, therefore this exercise is a first attempt to contribute to the growing literature on the consequences of child labor on the quality of schooling.

Brazil focused considerable efforts over the 2000s to improve the primary school access. In 2006, the government approved the National Education Plan (Plano Nacional de Educação - PNE) in order to address the barriers to the student access and to reduce the dropout rate. Twenty goals were set and one of them was to enroll every children between 6 and 14 years old in the primary school until 2016. In the same year, the Amendment to the Constitution 53/2006 created The Fund for the Maintenance and Development of Basic Education and Enhancement of Education Professionals (Fundo de Manutenção e Desenvolvimento da Educação Básica e de Valorização dos Profissionais da Educação - Fundeb), which replaced the Fund for the Maintenance and Development of Fundamental Education and Valorization of Teachers (Fundo 
Table 6 - Main results - The effects of trade shocks on school quality/quantity

\begin{tabular}{|c|c|c|c|c|c|c|c|c|}
\hline \multirow[t]{3}{*}{ Dependent Variable } & \multicolumn{2}{|c|}{ Expenditure per student } & \multicolumn{2}{|c|}{ Revenue per student } & \multicolumn{2}{|c|}{$\begin{array}{l}\text { Number of primary } \\
\text { schools per student }\end{array}$} & \multicolumn{2}{|c|}{ Student-Teacher ratio } \\
\hline & OLS & IV & OLS & IV & OLS & IV & OLS & IV \\
\hline & $(1)$ & $(2)$ & $(3)$ & $(4)$ & $(5)$ & (6) & $(7)$ & $(8)$ \\
\hline \multicolumn{9}{|l|}{ I. Overall Trade Shocks } \\
\hline Import Competition $\left(I S_{m}\right)$ & $\begin{array}{c}0.044 \\
(0.107)\end{array}$ & $\begin{array}{c}0.119 \\
(0.092)\end{array}$ & $\begin{array}{c}0.043 \\
(0.236)\end{array}$ & $\begin{array}{c}0.162 \\
(0.192)\end{array}$ & $\begin{array}{c}0.012 \\
(0.010)\end{array}$ & $\begin{array}{c}0.015 \\
(0.010)\end{array}$ & $\begin{array}{c}0.673 \\
(1.456)\end{array}$ & $\begin{array}{c}0.062 \\
(1.476)\end{array}$ \\
\hline Export Demand $\left(X D_{m}\right)$ & $\begin{array}{r}-0.096^{*} \\
(0.056)\end{array}$ & $\begin{array}{r}-0.116^{*} \\
(0.059)\end{array}$ & $\begin{array}{r}-0.118^{*} \\
(0.064)\end{array}$ & $\begin{array}{c}-0.140^{* *} \\
(0.065)\end{array}$ & $\begin{array}{r}-0.018^{*} \\
(0.010)\end{array}$ & $\begin{array}{l}-0.015 \\
(0.010)\end{array}$ & $\begin{array}{c}0.184 \\
(0.233)\end{array}$ & $\begin{array}{c}0.186 \\
(0.267)\end{array}$ \\
\hline \multicolumn{9}{|l|}{ II. Disaggregated Trade Shocks } \\
\hline Import Competition Concentrated on Adult & $\begin{array}{l}-0.018 \\
(0.107)\end{array}$ & $\begin{array}{c}0.056 \\
(0.097)\end{array}$ & $\begin{array}{l}-0.010 \\
(0.151)\end{array}$ & $\begin{array}{c}0.120 \\
(0.136)\end{array}$ & $\begin{array}{c}0.009 \\
(0.011)\end{array}$ & $\begin{array}{c}0.012 \\
(0.009)\end{array}$ & $\begin{array}{c}0.700 \\
(1.369)\end{array}$ & $\begin{array}{c}0.223 \\
(1.337)\end{array}$ \\
\hline Import Competition Concentrated on Child & $\begin{array}{l}0.101^{*} \\
(0.058)\end{array}$ & $\begin{array}{l}0.107^{*} \\
(0.065)\end{array}$ & $\begin{array}{c}0.095 \\
(0.065)\end{array}$ & $\begin{array}{c}0.045 \\
(0.076)\end{array}$ & $\begin{array}{l}0.006^{*} \\
(0.004)\end{array}$ & $\begin{array}{l}0.008^{* *} \\
(0.003)\end{array}$ & $\begin{array}{c}0.050 \\
(0.296)\end{array}$ & $\begin{array}{c}0.061 \\
(0.324)\end{array}$ \\
\hline Export Demand Concentrated on Adult & $\begin{array}{r}-0.098^{*} \\
(0.058)\end{array}$ & $\begin{array}{c}-0.111^{*} \\
(0.060)\end{array}$ & $\begin{array}{r}-0.094^{*} \\
(0.054)\end{array}$ & $\begin{array}{c}-0.118^{* *} \\
(0.055)\end{array}$ & $\begin{array}{c}-0.017^{*} \\
(0.010)\end{array}$ & $\begin{array}{l}-0.014 \\
(0.010)\end{array}$ & $\begin{array}{c}0.264 \\
(0.231)\end{array}$ & $\begin{array}{l}0.218 \\
(0.255)\end{array}$ \\
\hline Export Demand Concentrated on Child & $\begin{array}{c}0.039 \\
(0.061)\end{array}$ & $\begin{array}{l}-0.028 \\
(0.100)\end{array}$ & $\begin{array}{c}0.041 \\
(0.055)\end{array}$ & $\begin{array}{l}-0.028 \\
(0.057)\end{array}$ & $\begin{array}{l}-0.004 \\
(0.007)\end{array}$ & $\begin{array}{l}-0.011 \\
(0.013)\end{array}$ & $\begin{array}{c}-0.985^{* *} \\
(0.441)\end{array}$ & $\begin{array}{l}-1.459^{*} \\
(0.760)\end{array}$ \\
\hline Observations & 391 & 391 & 392 & 392 & 392 & 392 & 392 & 392 \\
\hline
\end{tabular}

de Manutenção e Desenvolvimento do Ensino Fundamental e de Valorização do Magistério Fundef) in order to increase the amount of resources allocated by Union, states and municipalities in public basic education and to improve the formation and wages of professionals involved with education.

Although there is no reason to suspect that these institutional reforms are correlated with trade shock exposure, these schooling changes could confound the results if schooling policy changes are correlated with the microregions' exposure to the Chinese trade shock. Moreover, these educational policies could have affected the returns to education attracting more children to school and reducing the number of working children. In any case, I mimic the main specification used in this paper and regress some measures of microregion school quantity and quality on the corresponding trade shock measure, labor market and demographic controls. I also control for initial per student education revenue and I find no evidence that changes in school availability or quality are substantively correlated to trade shock exposure, as can be seen in Table 6 . 



\section{Mechanisms}

Why does the child exposure to the import competition shock has a negative effect on the share of children that work and a positive effect on schooling outcomes? In this section I provide some initial evidence on the mechanisms that drive these effects. If the exposure to the import competition shock is associated with increases in poverty, schooling could decline, for example. As discussed by Edmonds, Pavcnik e Topalova (2010), lower living standards can force families to pull children out of school if there are direct or indirect costs associated with going to school. In order to test this prediction, Table 7 reports the effects of trade shock on some poverty measures, such as log difference in the average hourly wages of children aged 10-14, log difference in the household income per capita and $100 \mathrm{x}$ changes in the share of children living in household with income per capita lower than $\$ 255$ reals $^{1}$.

First, reductions in the returns to child labor might reduce the opportunity cost of attending school. Hence, if the countervailing substitution effect is sufficiently strong, it can cause a decrease in child labor and higher school attendance. According to point estimates of column (2) of Table 7, the average import trade shock on children is associated with a 2.4 percentage points decrease in children's wages between 2000 and 2010. Although child wages measures are subject to various measurement errors, the evidence suggests that reductions in returns to child labor might driven the results of Section 5. Columns (3) and (4) also reveals that log differences in household income per capita are negative associated with import competition shocks on children. According to the point estimates of column (4), on average, an increase in the import trade shock on children is associated with a $0.3 \%$ decrease in microregion's average household income per capita between 2000 and 2010. Hence, as suggested by a large empirical literature, this is an evidence that wealth effects can be an important mechanism behind lower schooling attainment.

Another evidence that lower schooling is the result of poverty is presented in columns (5) and (6), which reports the effects of trade exposure shocks on the percentage of children population living in households with income per capita lower than $\$ 255$ reals. According to

$1 \quad \$ 255$ is half of the minimum wage in 2010 . 
Table 7 - Mechanisms - The effects of trade shocks on poverty measures

\begin{tabular}{l}
\hline \hline Dependent Variable \\
\end{tabular}

point estimates of column (6), a microregion exposed to the average import competition shock on adults experienced an increase in the share of vulnerable children by 0.68 percentage points between 2000 and 2010. This evidence is in agreement with Costa, Garred e Pessoa (2016). The authors find that the estimated effect of Chinese import competition on wages is statistically insignificant, but this shock had a statistically significant effect on the wages of the sector most directly affected by it: manufacturing. The authors find that in microregions experiencing a US\$ 1000 higher rise in imports per worker, manufacturing workers' average wages rose 2.93 percentage points more slowly ${ }^{2}$.

On the other hand, changes in the composition of local employment across sectors in response to trade shocks may explain why children dropout labor market even when adults are exposed to adverse shocks. The main intuition is that in response to trade shocks, adult workers might be reallocated between the manufacturing and agriculture sectors. In order to test this prediction, Table 8 provides the IV results of the regressions in which the left-hand side variable

2 Their explanation for the statistically insignificant aggregated estimates is based on the relatively small share of total workers in manufacturing sectors, even in regions experiencing large import shocks. 
Table 8 - Mechanisms - The effects of trade shocks on employment composition patterns

\begin{tabular}{|c|c|c|c|c|c|c|c|c|}
\hline \multirow[t]{3}{*}{ Dependent Variable } & \multicolumn{2}{|c|}{ Agriculture } & \multicolumn{2}{|c|}{ Extractive } & \multicolumn{2}{|c|}{ Manufacturing } & \multicolumn{2}{|c|}{ Non Traded } \\
\hline & Adult & Child & Adult & Child & Adult & Child & Adult & Child \\
\hline & (1) & (2) & $(3)$ & $(4)$ & $(5)$ & (6) & $(7)$ & $(8)$ \\
\hline \multicolumn{9}{|l|}{ I. Overall Trade Shocks } \\
\hline$\left.\overline{\text { Import Competition }(I} S_{m}\right)$ & $\begin{array}{l}1.064^{* *} \\
(0.521)\end{array}$ & $\begin{array}{c}-0.475^{* * *} \\
(0.105)\end{array}$ & $\begin{array}{c}0.128 \\
(0.122)\end{array}$ & $\begin{array}{l}-0.001 \\
(0.001)\end{array}$ & $\begin{array}{c}-2.640^{* *} \\
(1.157)\end{array}$ & $\begin{array}{c}0.022 \\
(0.015)\end{array}$ & $\begin{array}{c}0.247 \\
(1.467)\end{array}$ & $\begin{array}{c}0.065 \\
(0.053)\end{array}$ \\
\hline Export Demand $\left(X D_{m}\right)$ & $\begin{array}{c}0.084 \\
(0.394)\end{array}$ & $\begin{array}{l}-0.033 \\
(0.044)\end{array}$ & $\begin{array}{c}0.346^{* *} \\
(0.150)\end{array}$ & $\begin{array}{c}-0.001 \\
(0.001)\end{array}$ & $\begin{array}{c}0.049 \\
(0.184)\end{array}$ & $\begin{array}{l}-0.000 \\
(0.007)\end{array}$ & $\begin{array}{l}-0.779 \\
(0.586)\end{array}$ & $\begin{array}{c}0.036^{* *} \\
(0.016)\end{array}$ \\
\hline \multicolumn{9}{|l|}{ II. Disaggregated Trade Shocks } \\
\hline Import Competition Concentrated on Adult & $\begin{array}{c}0.912^{* *} \\
(0.424)\end{array}$ & $\begin{array}{c}-0.447^{* * *} \\
(0.111)\end{array}$ & $\begin{array}{c}0.174 \\
(0.129)\end{array}$ & $\begin{array}{c}-0.001 \\
(0.001)\end{array}$ & $\begin{array}{c}-2.793^{* *} \\
(1.284)\end{array}$ & $\begin{array}{c}0.038^{* *} \\
(0.016)\end{array}$ & $\begin{array}{c}0.312 \\
(1.329)\end{array}$ & $\begin{array}{c}0.068 \\
(0.053)\end{array}$ \\
\hline Import Competition Concentrated on Child & $\begin{array}{l}-0.095 \\
(0.257)\end{array}$ & $\begin{array}{l}-0.045 \\
(0.032)\end{array}$ & $\begin{array}{l}-0.046 \\
(0.035)\end{array}$ & $\begin{array}{c}0.001 \\
(0.000)\end{array}$ & $\begin{array}{c}0.257 \\
(0.382)\end{array}$ & $\begin{array}{c}-0.024^{* *} \\
(0.010)\end{array}$ & $\begin{array}{c}0.458 \\
(0.449)\end{array}$ & $\begin{array}{c}0.011 \\
(0.020)\end{array}$ \\
\hline Export Demand Concentrated on Adult & $\begin{array}{l}-0.119 \\
(0.296)\end{array}$ & $\begin{array}{c}-0.032 \\
(0.050)\end{array}$ & $\begin{array}{c}0.366^{* *} \\
(0.159)\end{array}$ & $\begin{array}{l}-0.000 \\
(0.001)\end{array}$ & $\begin{array}{c}0.037 \\
(0.190)\end{array}$ & $\begin{array}{c}0.002 \\
(0.006)\end{array}$ & $\begin{array}{c}-0.448 \\
(0.342)\end{array}$ & $\begin{array}{c}0.046^{* * *} \\
(0.014)\end{array}$ \\
\hline Export Demand Concentrated on Child & $\begin{array}{c}1.402^{* * *} \\
(0.451)\end{array}$ & $\begin{array}{l}-0.010 \\
(0.084)\end{array}$ & $\begin{array}{c}-0.136 \\
(0.129)\end{array}$ & $\begin{array}{c}-0.004^{* * *} \\
(0.001)\end{array}$ & $\begin{array}{c}0.069 \\
(0.418)\end{array}$ & $\begin{array}{l}-0.010 \\
(0.012)\end{array}$ & $\begin{array}{c}-2.273^{* * *} \\
(0.535)\end{array}$ & $\begin{array}{c}-0.065^{* *} \\
(0.028)\end{array}$ \\
\hline Observations & 413 & 413 & 413 & 413 & 413 & 413 & 413 & 413 \\
\hline
\end{tabular}

is the long difference between 2000 and 2010 in the share of employed individuals (adults or children) working in each sector: agriculture, extractive, manufacturing and nontraded. The evidence confirms the prediction. Adverse shocks on adults increase (decrease) the share of adults (children) employed in agriculture, which is the most important sector for child labor. The result is an evidence of the movement of adult workers from manufacturing sectors into children vacancies in agriculture, which may explain the decline in the share of working children between 2000 and 2010. This result can also help to explain why the share of idle children increased in response to an adverse shock on adult. As Duryea e Arends-Kuenning (2003) argue, children that are out of the labor market might be working on domestic activities that prevent them from attending school, which allows that other members of the family search for a job in the market. Due to the data limitation, I can not disaggregate child labor into domestic and market activities. 



\section{Heterogeneous Effects}

I also estimate Equation (4.3) separately for children living in urban and rural areas in order to see heterogeneous effects on these two groups. The results are presented in Table 9 and reveals that the effects of trade shock exposure on children activities are higher in children living in rural areas. On average, an import competition on children decreased the share of children that work and study part-time in 0.37 percentage points, impact six times greater than the overall effect presented in Table 4. In the same way, the share of children that attend school full-time in rural areas are much more responsive than those who live in urban regions. On the other hand, import competition shocks on adults have a negative effect on the share of children that work and study part-time, but do not increase idleness or the share of children that attend school full-time. One possibility is that part of the households affected by the shock is allocating children to activities related to school and part to domestic work or idleness.

I also estimate heterogenous effects for school performance outcomes. Table 10 presents the results, which should be interpreted with caution, as the number of observations for rural schools are very low compared to the main exercise. The results for the children who live in urban areas are essentially the same as in Table 5, except for the negative effect of import competition on adult-intensive sectors on the share of children that do math homework. On the other hand, the point estimates are statistically insignificant for children who live in rural regions. 
Table 9 - Heterogeneous effects - The effects of trade shocks on children living in urban/rural areas

\begin{tabular}{|c|c|c|c|c|c|c|c|c|}
\hline \multirow[t]{3}{*}{ Dependent Variable } & \multicolumn{2}{|c|}{ Attend school only } & \multicolumn{2}{|c|}{ Work only } & \multicolumn{2}{|c|}{ Work and study } & \multicolumn{2}{|c|}{ Idle } \\
\hline & Urban & Rural & Urban & Rural & Urban & Rural & Urban & Rural \\
\hline & (1) & $(2)$ & (3) & (4) & (5) & (6) & (7) & (8) \\
\hline \multicolumn{9}{|l|}{ I. Overall Trade Shocks } \\
\hline Import Competition $\left(I S_{m}\right)$ & $\begin{array}{c}0.307 \\
(0.327)\end{array}$ & $\begin{array}{c}3.936^{* *} \\
(1.898)\end{array}$ & $\begin{array}{l}-0.035 \\
(0.073)\end{array}$ & $\begin{array}{l}-0.756 \\
(0.587)\end{array}$ & $\begin{array}{c}-0.374^{*} \\
(0.193)\end{array}$ & $\begin{array}{c}-4.838^{* * *} \\
(0.781)\end{array}$ & $\begin{array}{c}0.102 \\
(0.178)\end{array}$ & $\begin{array}{l}1.658 \\
(1.140)\end{array}$ \\
\hline Export Demand $\left(X D_{m}\right)$ & $\begin{array}{l}-0.121 \\
(0.105)\end{array}$ & $\begin{array}{l}-0.154 \\
(0.445)\end{array}$ & $\begin{array}{c}0.013 \\
(0.024)\end{array}$ & $\begin{array}{c}0.093 \\
(0.155)\end{array}$ & $\begin{array}{c}0.093 \\
(0.086)\end{array}$ & $\begin{array}{l}-0.236 \\
(0.276)\end{array}$ & $\begin{array}{l}0.016 \\
(0.067)\end{array}$ & $\begin{array}{l}0.297^{*} \\
(0.166)\end{array}$ \\
\hline \multicolumn{9}{|l|}{ II. Disaggregated Trade Shocks } \\
\hline Import Competition Concentrated on Adult & $\begin{array}{c}0.219 \\
(0.345)\end{array}$ & $\begin{array}{l}3.270 \\
(2.015)\end{array}$ & $\begin{array}{c}0.001 \\
(0.077)\end{array}$ & $\begin{array}{l}-0.736 \\
(0.624)\end{array}$ & $\begin{array}{l}-0.295 \\
(0.208)\end{array}$ & $\begin{array}{c}-4.166^{* * *} \\
(0.794)\end{array}$ & $\begin{array}{c}0.075 \\
(0.172)\end{array}$ & $\begin{array}{c}1.632 \\
(1.144)\end{array}$ \\
\hline Import Competition Concentrated on Child & $\begin{array}{c}0.144 \\
(0.133)\end{array}$ & $\begin{array}{c}1.092^{* * *} \\
(0.391)\end{array}$ & $\begin{array}{l}-0.039 \\
(0.027)\end{array}$ & $\begin{array}{l}-0.034 \\
(0.171)\end{array}$ & $\begin{array}{l}-0.082 \\
(0.087)\end{array}$ & $\begin{array}{c}-1.062^{* * *} \\
(0.275)\end{array}$ & $\begin{array}{l}-0.023 \\
(0.072)\end{array}$ & $\begin{array}{c}0.003 \\
(0.225)\end{array}$ \\
\hline Export Demand Concentrated on Adult & $\begin{array}{l}-0.134 \\
(0.105)\end{array}$ & $\begin{array}{l}-0.259 \\
(0.482)\end{array}$ & $\begin{array}{c}0.028 \\
(0.024)\end{array}$ & $\begin{array}{c}0.094 \\
(0.166)\end{array}$ & $\begin{array}{l}0.125 \\
(0.082)\end{array}$ & $\begin{array}{l}-0.112 \\
(0.314)\end{array}$ & $\begin{array}{l}-0.019 \\
(0.067)\end{array}$ & $\begin{array}{l}0.277^{*} \\
(0.167)\end{array}$ \\
\hline Export Demand Concentrated on Child & $\begin{array}{c}0.082 \\
(0.231)\end{array}$ & $\begin{array}{c}0.686 \\
(0.637)\end{array}$ & $\begin{array}{c}-0.101^{*} \\
(0.057)\end{array}$ & $\begin{array}{l}-0.016 \\
(0.222)\end{array}$ & $\begin{array}{l}-0.225 \\
(0.225)\end{array}$ & $\begin{array}{c}-0.811^{*} \\
(0.493)\end{array}$ & $\begin{array}{c}0.245 \\
(0.152)\end{array}$ & $\begin{array}{c}0.141 \\
(0.369)\end{array}$ \\
\hline Observations & 413 & 412 & 413 & 412 & 413 & 412 & 413 & 412 \\
\hline
\end{tabular}

Table 10 - Heterogeneous effects - The effects of trade shocks on school performance in urban/rural areas

\begin{tabular}{|c|c|c|c|c|c|c|c|c|}
\hline \multirow[t]{3}{*}{ Dependent Variable } & \multicolumn{2}{|c|}{ Math score } & \multicolumn{2}{|c|}{ Portuguese score } & \multicolumn{2}{|c|}{ Math Homework } & \multicolumn{2}{|c|}{ Portuguese Homework } \\
\hline & Urban & Rural & Urban & Rural & Urban & Rural & Urban & Rural \\
\hline & (1) & $(2)$ & (3) & (4) & (5) & $(6)$ & (7) & (8) \\
\hline \multicolumn{9}{|l|}{ I. Overall Trade Shocks } \\
\hline Import Competition $\left(I S_{m}\right)$ & $\begin{array}{l}-0.018 \\
(0.032)\end{array}$ & $\begin{array}{c}0.159 \\
(0.169)\end{array}$ & $\begin{array}{l}-0.025 \\
(0.039)\end{array}$ & $\begin{array}{l}-0.117 \\
(0.146)\end{array}$ & $\begin{array}{l}-4.709^{*} \\
(2.842)\end{array}$ & $\begin{array}{l}-19.556 \\
(23.373)\end{array}$ & $\begin{array}{l}-1.037 \\
(2.993)\end{array}$ & $\begin{array}{c}11.327 \\
(21.517)\end{array}$ \\
\hline Export Demand $\left(X D_{m}\right)$ & $\begin{array}{l}-0.012 \\
(0.009)\end{array}$ & $\begin{array}{l}-0.012 \\
(0.018)\end{array}$ & $\begin{array}{l}-0.011 \\
(0.011)\end{array}$ & $\begin{array}{l}-0.003 \\
(0.021)\end{array}$ & $\begin{array}{c}1.599 \\
(2.228)\end{array}$ & $\begin{array}{l}-1.788 \\
(2.530)\end{array}$ & $\begin{array}{c}0.619 \\
(1.083)\end{array}$ & $\begin{array}{c}0.316 \\
(2.407)\end{array}$ \\
\hline \multicolumn{9}{|l|}{ II. Disaggregated Trade Shocks } \\
\hline Import Competition Concentrated on Adult & $\begin{array}{l}-0.028 \\
(0.027)\end{array}$ & $\begin{array}{c}0.146 \\
(0.146)\end{array}$ & $\begin{array}{l}-0.033 \\
(0.035)\end{array}$ & $\begin{array}{l}-0.114 \\
(0.146)\end{array}$ & $\begin{array}{c}-5.334^{* *} \\
(2.653)\end{array}$ & $\begin{array}{l}-19.715 \\
(20.696)\end{array}$ & $\begin{array}{l}-2.858 \\
(3.330)\end{array}$ & $\begin{array}{c}8.921 \\
(19.508)\end{array}$ \\
\hline Import Competition Concentrated on Child & $\begin{array}{l}0.024^{*} \\
(0.014)\end{array}$ & $\begin{array}{l}0.011 \\
(0.025)\end{array}$ & $\begin{array}{l}0.017 \\
(0.011)\end{array}$ & $\begin{array}{l}-0.020 \\
(0.021)\end{array}$ & $\begin{array}{l}1.428 \\
(2.035)\end{array}$ & $\begin{array}{l}-3.001 \\
(3.941)\end{array}$ & $\begin{array}{c}3.827 \\
(3.721)\end{array}$ & $\begin{array}{c}1.032 \\
(4.110)\end{array}$ \\
\hline Export Demand Concentrated on Adult & $\begin{array}{l}-0.012 \\
(0.010)\end{array}$ & $\begin{array}{l}-0.024 \\
(0.017)\end{array}$ & $\begin{array}{l}-0.011 \\
(0.012)\end{array}$ & $\begin{array}{l}-0.006 \\
(0.024)\end{array}$ & $\begin{array}{l}1.628 \\
(2.323)\end{array}$ & $\begin{array}{l}-3.548 \\
(2.902)\end{array}$ & $\begin{array}{c}0.612 \\
(1.137)\end{array}$ & $\begin{array}{l}-1.882 \\
(2.649)\end{array}$ \\
\hline Export Demand Concentrated on Child & $\begin{array}{l}-0.010 \\
(0.014)\end{array}$ & $\begin{array}{l}0.042^{*} \\
(0.022)\end{array}$ & $\begin{array}{l}-0.005 \\
(0.013)\end{array}$ & $\begin{array}{c}0.012 \\
(0.022)\end{array}$ & $\begin{array}{l}-0.569 \\
(1.318)\end{array}$ & $\begin{array}{c}6.109 \\
(5.157)\end{array}$ & $\begin{array}{l}-0.876 \\
(1.598)\end{array}$ & $\begin{array}{c}7.735 \\
(4.855)\end{array}$ \\
\hline Observations & 312 & 142 & 312 & 142 & 312 & 142 & 312 & 142 \\
\hline $\begin{array}{l}\text { his table displays heterogeneous effects of Chinese } \\
\text { ea. Math and portuguese scores in columns (1) to } \\
\text { anges in the share of children that do homework. } \\
\text { easures. All regressions include a constant and the } \\
\text { ctors, } 2000 \text { share of workforce in manufacturing, } \\
\text { ontrols such as the } 2000 \text { average household income, } \\
\text { onwhite, the } 2000 \text { share of population that are fem } \\
\text { umber of schools per student and the } 2000 \text { student } \\
\text { tandard errors are clustered by mesoregion, } 91 \text { clus }\end{array}$ & th and & 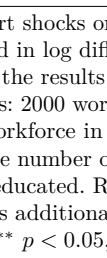 & 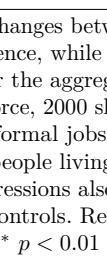 & 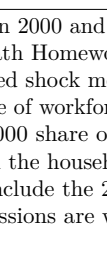 & in sch & mance & ors acc & geogra \\
\hline
\end{tabular}




\section{Concluding Remarks}

Child labor is still a relevant problem in developing countries and understanding the way that households respond in terms of children's time allocation to labor market incentives has relevant policy implications. Although a large body of theoretical and empirical literature emerged in recent years in order to explain the causes of child labor, the issue is still a challenge to the researchers. In this paper, I explore a plausibly exogenous trade-induced labor market shock to assess how changes in returns to work affect children's time allocation in Brazil. To provide a good proxy for distinctly exogenous changes to the returns to adult labor as well as returns to the child labor I propose a strategy that distinguish between employment shocks that differentially affect adults and children. The results suggest an asymmetric impact on household decisions about children's time allocation that depend upon the source of the shock.

First, I find that larger import competition shocks to adult and child-intensive sectors have opposite signed effects on school attendance. Conditional on child labor market shocks, larger import competition shocks concentrated on adult decrease the share of children that attend school, while conditional on adult labor market shocks, an adverse shock concentrated on children has a positive effect on schooling, but the estimates are not statistically significant. On the other hand, both shocks decrease the share of working children, in particular those who combine work and school. However, shock on adults increase idleness, while shocks on children increase the share of children that attend school full-time.

Second, I examine if there is any effect on school performance and find that import competition shocks on children is associated with an increase in microregion's average math score between 2001 and 2011. Next, I explore the mechanisms behind the results and distinguish two possibilities. First, I provide evidence that import competition shocks are associated with lower children's wages, lower household income per capita and higher share of children living in vulnerable conditions. On the other hand, adverse shocks on adults increase (decrease) the share of adults (children) employed in agriculture, which is the most important sector for child labor. The result is an evidence of the movement of adult workers from manufacturing sectors into children vacancies in agriculture, which may explain the decline in the share of working 
children between 2000 and 2010. Finally, I examine whether the effects are heterogeneous for children living in urban and rural households and I find that adverse import competition shocks have a strong effect for rural children, but not for the urban ones.

Although the magnitudes of the effects are not substantially big, the results suggest that policy makers must be careful in designing policies because different economic shocks that affect different groups of people have distinct effects on school attainment and labor market outcomes. The contribution of this paper is to propose a strategy that exploits these differences in industry specialization by age to identify trade shocks that differently affect adult's and child's employment outcomes. 


\section{Bibliography}

ACEMOGLU, D. et al. Import competition and the great us employment sag of the 2000s. Journal of Labor Economics, University of Chicago Press Chicago, IL, v. 34, n. S1, p. S141-S198, 2016. 17

ATKIN, D. Endogenous skill acquisition and export manufacturing in mexico. American Economic Review, v. 106, n. 8, p. 2046-85, August 2016. Disponível em: <http: //www.aeaweb.org/articles?id=10.1257/aer.20120901>. 17

AUTOR, D. H.; DORN, D.; HANSON, G. H. The china syndrome: Local labor market effects of import competition in the united states. The American Economic Review, American Economic Association, v. 103, n. 6, p. 2121-2168, 2013. 14, 17

BAI, J. Returns to work and children's schooling: Separating the income and substitution effects. Working Paper. 2016. 15, 17, 31, 32

BALAND, J.-M.; ROBINSON, J. A. Is child labor inefficient? Journal of Political Economy, The University of Chicago Press, v. 108, n. 4, p. 663-679, 2000. 13

BARROS, R. P. de; MENDONÇA, R. Trabalho infantil no brasil: rumo à erradicação. Texto para Discussão, Instituto de Pesquisa Econômica Aplicada (IPEA). 2010. 16, 23

BASU, K.; VAN, P. H. The economics of child labor. The American Economic Review, American Economic Association, v. 88, n. 3, p. 412-427, 1998. ISSN 00028282. Disponível em: $<$ http://www.jstor.org/stable/116842>. 13

BEEGLE, K.; DEHEJIA, R. H.; GATTI, R. Child labor and agricultural shocks. Journal of Development Economics, v. 81, n. 1, p. 80 - 96, 2006. ISSN 0304-3878. Disponível em: <http://www.sciencedirect.com/science/article/pii/S0304387805000829>. 13, 17

BIGGERI, M. et al. The puzzle of "idle" children: Neither in school nor performing economic activity. evidence from six countries. Working paper. 2003. 19, 20

COSTA, F.; GARRED, J.; PESSOA, J. P. Winners and losers from a commodities-formanufactures trade boom. Journal of International Economics, Elsevier, v. 102, p. 50-59, 2016. $14,15,24,29,32,33,44,55$

DIX-CARNEIRO, R.; KOVAK, B. K. Trade liberalization and the skill premium: A local labor markets approach. The American Economic Review, American Economic Association, v. 105, n. 5 , p. $551-557,2015.17,55$

DIX-CARNEIRO, R.; KOVAK, B. K. Trade liberalization and regional dynamics. American Economic Review, ., p. Forthcoming, 2017. ISSN 0305-750X. Disponível em: $<$ https://www.aeaweb.org/articles?id=10.1257/aer.20161214\&\&from $=$ f $>.55$

DUMAS, C. Does work impede child learning? the case of senegal. Economic Development and Cultural Change, University of Chicago Press Chicago, IL, v. 60, n. 4, p. 773-793, 2012. 17

DURYEA, S.; ARENDS-KUENNING, M. School attendance, child labor and local labor market fluctuations in urban brazil. World Development, v. 31, n. 7, p. $1165-1178$, 2003. ISSN 0305-750X. Economic Crises, Natural Disasters, and Poverty. Disponível em: <http://www.sciencedirect.com/science/article/pii/S0305750X03000652>. 13, 17, 45 
EDMONDS, E. V.; PAVCNIK, N. The effect of trade liberalization on child labor. Journal of International Economics, Elsevier, v. 65, n. 2, p. 401-419, 2005. 13, 17

EDMONDS, E. V.; PAVCNIK, N.; TOPALOVA, P. Trade adjustment and human capital investments: Evidence from indian tariff reform. American Economic Journal: Applied Economics, American Economic Association, v. 2, n. 4, p. 42-75, 2010. 13, 17, 37, 43

EMERSON, P. M.; PONCZEK, V.; SOUZA, A. P. Child labor and learning. Economic Development and Cultural Change, University of Chicago Press Chicago, IL, v. 65, n. 2, p. 000-000, 2017. 17, 40

EMERSON, P. M.; SOUZA, A. P. Is there a child labor trap? intergenerational persistence of child labor in brazil. Economic Development and Cultural Change, The University of Chicago Press, v. 51, n. 2, p. 375-398, 2003. 13

FRYER, R. G. Injecting charter school best practices into traditional public schools: Evidence from field experiments. The Quarterly Journal of Economics, Oxford University Press, v. 129, n. 3 , p. $1355-1407,2014.40$

GONZAGA, G.; FILHO, N. M.; TERRA, C. Trade liberalization and the evolution of skill earnings differentials in brazil. Journal of International Economics, Elsevier, v. 68, n. 2, p. 345-367, 2006. 17

GREENLAND, A.; LOPRESTI, J. Import exposure and human capital adjustment: Evidence from the us. Journal of International Economics, Elsevier, v. 100, p. 50-60, 2016. 17

IBGE. Censo demográfico 2000: Documentação dos microdados da amostra. IBGE. 2002. 25

International Labor Organization. Minimum age convention, c138. International Labor Organization. 1973. 25

International Labor Organization. Marking progress against child labour - global estimates and trends 2000-2012. International Labor Organization. 2013. 13

KRUGER, D. I. Coffee production effects on child labor and schooling in rural brazil. Journal of Development Economics, Elsevier, v. 82, n. 2, p. 448-463, 2007. 13, 17

MENEZES-FILHO, N. A.; MUENDLER, M. A. Labor reallocation in response to trade reform. National Bureau of Economic Research, Working Paper Series 17372. 2011. Disponível em: <http://www.nber.org/papers/w17372>. 55

MONTEIRO, J.; ROCHA, R. Drug battles and school achievement: evidence from rio de janeiro's favelas. Review of Economics and Statistics, MIT Press, n. 0, 2012. 40

REIS, E.; PIMENTEL, M.; ALVARENGA, A. I. Áreas mínimas comparáveis para os períodos intercensitários de 1872 a 2000. IPEA. Rio de Janeiro. 2007. 25

ROSENZWEIG, M. R.; EVENSON, R. Fertility, schooling, and the economic contribution of children of rural india: An econometric analysis. Econometrica, [Wiley, Econometric Society], v. 45, n. 5, p. 1065-1079, 1977. ISSN 00129682, 14680262. Disponível em: $<$ http://www.jstor.org/stable/1914059>. 13, 17 
SOARES, R. R.; KRUGER, D.; BERTHELON, M. Household choices of child labor and schooling a simple model with application to brazil. Journal of Human Resources, University of Wisconsin Press, v. 47, n. 1, p. 1-31, 2012. 13, 17, 19

TOPALOVA, P. Factor immobility and regional impacts of trade liberalization: Evidence on poverty from india. American Economic Journal: Applied Economics, American Economic Association, v. 2, n. 4, p. 1-41, 2010. 17

World Trade Organization. World trade statistical review. World Trade Organization. 2016. 24

ZABALETA, M. B. The impact of child labor on schooling outcomes in nicaragua. Economics of Education Review, Elsevier, v. 30, n. 6, p. 1527-1539, 2011. 17 



\section{Appendix A. Robustness of Main Results}

One potential concern with the empirical analysis is that the results observed in the Section 5 simply represent the continuation of local child labor and schooling trends that began in years before the period of study. As shown by Table 1, the declining trend in child labor is very clear in Brazil, as well as the increasing trend in school attendance. Similarly, as pointed out by Costa, Garred e Pessoa (2016), the trade liberalization episode in the late 1980s and early 1990s had a significant impact on affected local labor markets (see, e.g., Dix-Carneiro e Kovak (2017); Dix-Carneiro e Kovak (2015); Menezes-Filho e Muendler (2011)) and the adjustments resulting from this shock might still have been occurring.

Thus, in order to account for pre-sample period trends, I follow Costa, Garred e Pessoa (2016) and use data from the 1980 and 1991 Brazilian Demographic Census to add two lags of the dependent variable to the set of controls. This means that I estimate Equation (4.3) controlling for the microregion-level changes between 1991 and 200 and between 1980 and 1991 in the outcome of interest. Because of the possible correlation between the first lagged dependent variable and the error term, I follow Costa, Garred e Pessoa (2016) and instrument for this variable using 1991 levels. Table A1 shows that the main results are qualitatively unchanged by the specifications including two lags of the dependent variable.

I also mimic the main results using an alternative trade shock measure for adult and child exposure. In Equation 4.2, instead of dividing by the Brazilian child/adult workforce in sector $j$, I use the total workforce in the respectively sector, that is, $L_{j, 2000}$. Table A2 presents the IV results using these alternative measures and the same specifications used in the empirical strategy. As can be seen, all the results are qualitatively unchanged. 
Table A1 - Robustness regressions - The effects of trade shocks on children activities

\begin{tabular}{|c|c|c|c|c|c|c|}
\hline \multirow[t]{2}{*}{ Dependent Variable } & $\begin{array}{l}\text { Attend } \\
\text { school }\end{array}$ & $\begin{array}{l}\text { Attend } \\
\text { school only }\end{array}$ & Work & Work only & $\begin{array}{l}\text { Work and } \\
\text { study }\end{array}$ & Idle \\
\hline & (1) & $(2)$ & (3) & $(4)$ & (5) & $(6)$ \\
\hline \multicolumn{7}{|l|}{ I. Overall Trade Shocks } \\
\hline Import Competition $\left(I S_{m}\right)$ & $\begin{array}{c}-1.298^{*} \\
(0.754)\end{array}$ & $\begin{array}{c}0.239 \\
(0.760)\end{array}$ & $\begin{array}{c}-1.333^{* * *} \\
(0.274)\end{array}$ & $\begin{array}{c}0.034 \\
(0.135)\end{array}$ & $\begin{array}{c}-1.245^{* * *} \\
(0.279)\end{array}$ & $\begin{array}{c}1.285^{* *} \\
(0.599)\end{array}$ \\
\hline Export Demand $\left(X D_{m}\right)$ & $\begin{array}{l}-0.196 \\
(0.144)\end{array}$ & $\begin{array}{l}-0.136 \\
(0.170)\end{array}$ & $\begin{array}{c}0.062 \\
(0.115)\end{array}$ & $\begin{array}{l}0.113^{*} \\
(0.061)\end{array}$ & $\begin{array}{l}-0.034 \\
(0.099)\end{array}$ & $\begin{array}{c}0.084 \\
(0.092)\end{array}$ \\
\hline \multicolumn{7}{|l|}{ II. Disaggregated Trade Shocks } \\
\hline Import Competition Concentrated on Adult & $\begin{array}{c}-1.377^{*} \\
(0.781)\end{array}$ & $\begin{array}{l}-0.045 \\
(0.845)\end{array}$ & $\begin{array}{c}-1.055^{* * *} \\
(0.291)\end{array}$ & $\begin{array}{l}0.070 \\
(0.141)\end{array}$ & $\begin{array}{c}-0.948^{* * *} \\
(0.275)\end{array}$ & $\begin{array}{l}1.340^{* *} \\
(0.630)\end{array}$ \\
\hline Import Competition Concentrated on Child & $\begin{array}{c}0.173 \\
(0.144)\end{array}$ & $\begin{array}{c}0.369^{* *} \\
(0.169)\end{array}$ & $\begin{array}{c}-0.246^{* *} \\
(0.109)\end{array}$ & $\begin{array}{l}-0.066 \\
(0.043)\end{array}$ & $\begin{array}{l}-0.147 \\
(0.095)\end{array}$ & $\begin{array}{l}-0.114 \\
(0.127)\end{array}$ \\
\hline Export Demand Concentrated on Adult & $\begin{array}{l}-0.192 \\
(0.143)\end{array}$ & $\begin{array}{l}-0.225 \\
(0.191)\end{array}$ & $\begin{array}{c}0.152 \\
(0.144)\end{array}$ & $\begin{array}{l}0.115^{*} \\
(0.059)\end{array}$ & $\begin{array}{c}0.057 \\
(0.126)\end{array}$ & $\begin{array}{c}0.085 \\
(0.090)\end{array}$ \\
\hline Export Demand Concentrated on Child & $\begin{array}{l}-0.043 \\
(0.290)\end{array}$ & $\begin{array}{c}0.610^{* *} \\
(0.305)\end{array}$ & $\begin{array}{c}-0.628^{* *} \\
(0.257)\end{array}$ & $\begin{array}{l}-0.014 \\
(0.102)\end{array}$ & $\begin{array}{c}-0.593^{* *} \\
(0.256)\end{array}$ & $\begin{array}{l}-0.001 \\
(0.254)\end{array}$ \\
\hline Observations & 412 & 412 & 412 & 412 & 412 & 412 \\
\hline State fixed effects & Yes & Yes & Yes & Yes & Yes & Yes \\
\hline Lag dep. variable & Yes & Yes & Yes & Yes & Yes & Yes \\
\hline
\end{tabular}

This table reports the regression results of the robustness check of the main results. Dependent variables are the share of children that attend school, the share of children that work, the share of children that work and attend school part-time and the percentage of children that does not work and does not attend school (idle). Panel I displays the results for the aggregated shock measures, while Panel II shows the results for the disaggregated measures. All regressions include a constant and the following controls: 2000 workforce, 2000 share of workforce in agricultural sectors, 2000 share of workforce in extractive sectors, 2000 share of workforce in manufacturing, 2000 share of workforce in informal jobs, 2000 share of workforce in rural areas and microregion-level demographic controls such as the 2000 average household income, the 2000 average number of people living in the household, the 2000 percentage of a microregion's population that is nonwhite, the 2000 share of population that are female and college-educated, and the 2000 percentage of a microregion's population in 6 age groups. Regressions are weighted by the share of national children population in 2000. Standard errors are clustered by mesoregion, 91 clusters. ${ }^{* * *} \mathrm{p}<0.01,{ }^{* *} \mathrm{p}<0.05,{ }^{*} \mathrm{p}<0.1 * p<0.1,{ }^{* *} p<0.05,{ }^{* * *} p<0.01$

Table A2 - Robustness regressions - The effects of trade shocks on children activities (alternative measures for trade shock exposure)

\begin{tabular}{|c|c|c|c|c|c|c|}
\hline \multirow[t]{2}{*}{ Dependent Variable } & $\begin{array}{l}\text { Attend } \\
\text { school }\end{array}$ & $\begin{array}{l}\text { Attend } \\
\text { school only }\end{array}$ & Work & Work only & $\begin{array}{l}\text { Work and } \\
\text { study }\end{array}$ & Idle \\
\hline & (1) & $(2)$ & (3) & (4) & $(5)$ & (6) \\
\hline \multicolumn{7}{|l|}{ I. Overall Trade Shocks } \\
\hline Import Competition $\left(I S_{m}\right)$ & $\begin{array}{c}-1.408^{*} \\
(0.796)\end{array}$ & $\begin{array}{l}-0.048 \\
(0.796)\end{array}$ & $\begin{array}{c}-1.367^{* * *} \\
(0.255)\end{array}$ & $\begin{array}{l}-0.007 \\
(0.113)\end{array}$ & $\begin{array}{c}-1.360^{* * *} \\
(0.270)\end{array}$ & $\begin{array}{c}1.415^{* *} \\
(0.719)\end{array}$ \\
\hline Export Demand $\left(X D_{m}\right)$ & $\begin{array}{c}-0.224^{*} \\
(0.124)\end{array}$ & $\begin{array}{l}-0.152 \\
(0.169)\end{array}$ & $\begin{array}{c}0.033 \\
(0.124)\end{array}$ & $\begin{array}{l}0.105^{*} \\
(0.058)\end{array}$ & $\begin{array}{l}-0.072 \\
(0.108)\end{array}$ & $\begin{array}{c}0.119 \\
(0.082)\end{array}$ \\
\hline \multicolumn{7}{|l|}{ II. Disaggregated Trade Shocks } \\
\hline Import Competition Concentrated on Adult & $\begin{array}{c}-1.469^{*} \\
(0.812)\end{array}$ & $\begin{array}{l}-0.168 \\
(0.800)\end{array}$ & $\begin{array}{c}-1.290^{* * *} \\
(0.248)\end{array}$ & $\begin{array}{c}0.011 \\
(0.117)\end{array}$ & $\begin{array}{c}-1.300^{* * *} \\
(0.270)\end{array}$ & $\begin{array}{l}1.458^{* *} \\
(0.731)\end{array}$ \\
\hline Import Competition Concentrated on Child & $\begin{array}{c}35.796 \\
(32.357)\end{array}$ & $\begin{array}{c}83.188^{* *} \\
(39.080)\end{array}$ & $\begin{array}{c}-58.509^{* *} \\
(28.984)\end{array}$ & $\begin{array}{r}-11.117 \\
(8.980)\end{array}$ & $\begin{array}{c}-47.392^{*} \\
(26.704)\end{array}$ & $\begin{array}{c}-24.679 \\
(29.426)\end{array}$ \\
\hline Export Demand Concentrated on Adult & $\begin{array}{c}-0.205^{*} \\
(0.122)\end{array}$ & $\begin{array}{l}-0.220 \\
(0.184)\end{array}$ & $\begin{array}{c}0.122 \\
(0.145)\end{array}$ & $\begin{array}{l}0.107^{*} \\
(0.056)\end{array}$ & $\begin{array}{c}0.015 \\
(0.123)\end{array}$ & $\begin{array}{c}0.099 \\
(0.082)\end{array}$ \\
\hline Export Demand Concentrated on Child & $\begin{array}{l}-10.638 \\
(25.351)\end{array}$ & $\begin{array}{c}18.878 \\
(36.673)\end{array}$ & $\begin{array}{l}-28.855 \\
(26.705)\end{array}$ & $\begin{array}{c}0.661 \\
(7.746)\end{array}$ & $\begin{array}{l}-29.515 \\
(22.975)\end{array}$ & $\begin{array}{c}9.977 \\
(21.772)\end{array}$ \\
\hline
\end{tabular}

Observations

413

413

413

413

413

413

This table reports the regression results of the robustness check of the main results using alternative measures for trade shock exposure. Dependent variables are the share of children that attend school, the share of children that work, the share of children that work and attend school part-time and the percentage of children that does not work and does not attend school (idle). Panel I displays the results for the aggregated shock measures, while Panel II shows the results for the disaggregated measures. All regressions include a constant and the following controls: 2000 workforce, 2000 share of workforce in agricultural sectors, 2000 share of workforce in extractive sectors, 2000 share of workforce in manufacturing, 2000 share of workforce in informal jobs, 2000 share of workforce in rural areas and microregion-level demographic controls such as the 2000 average household income, the 2000 average number of people living in the household, the 2000 percentage of a microregion's population that is nonwhite, the 2000 share of population that are female and college-educated, and the 2000 percentage of a microregion's population in 6 age groups. Regressions are weighted by the share of national children population in 2000. Standard errors are clustered by mesoregion, 91 clusters. ${ }^{* * *} \mathrm{p}<0.01,{ }^{* *} \mathrm{p}<0.05,{ }^{*} \mathrm{p}<0.1{ }^{*} p<0.1,{ }^{* *} p<0.05,{ }^{* * *} p<0.01$ 


\section{Appendix B. Appendix Figures and Tables}

Table B1 - Additional summary statistics - Child labor intensity and trade exposure measures by sector

\begin{tabular}{|c|c|c|c|c|c|c|c|}
\hline & \multirow{3}{*}{$\begin{array}{l}\text { Child labor } \\
\text { intensity (\%) } \\
\text { (1) }\end{array}$} & \multirow{3}{*}{$\begin{array}{c}\text { Import } \\
\text { share } \\
\\
(2)\end{array}$} & \multirow{3}{*}{$\begin{array}{c}\text { Export } \\
\text { share } \\
\\
(3)\end{array}$} & \multicolumn{2}{|c|}{$\begin{array}{l}\text { Export demand } \\
\text { to China }\end{array}$} & \multicolumn{2}{|c|}{$\begin{array}{l}\text { Import supply } \\
\text { from China }\end{array}$} \\
\hline & & & & Adult & Child & Adult & Child \\
\hline & & & & $(4)$ & (5) & (6) & $(7)$ \\
\hline agriculture - rice & 5.89 & 0.000 & 0.000 & 0.00 & 0.00 & 0.00 & 0.00 \\
\hline agriculture - maize & 7.36 & 0.000 & 0.000 & 0.29 & 0.31 & 0.00 & 0.00 \\
\hline agriculture - other cereals & 5.36 & 0.000 & 0.000 & 0.00 & 0.00 & 0.03 & 0.04 \\
\hline agriculture - cotton & 7.45 & 0.000 & 0.005 & 10.11 & 10.13 & -0.19 & -0.19 \\
\hline agriculture - sugar cane & 1.36 & 0.000 & 0.000 & 0.00 & 0.00 & 0.00 & 0.00 \\
\hline agriculture - tobacco & 7.72 & 0.000 & 0.010 & 12.84 & 13.89 & -0.01 & -0.01 \\
\hline agriculture - soya & 3.37 & 0.000 & 0.229 & 256.89 & 125.07 & 0.00 & 0.00 \\
\hline agriculture - manioc & 8.04 & 0.000 & 0.000 & 0.00 & 0.00 & 0.00 & 0.00 \\
\hline $\begin{array}{l}\text { agriculture - flowers and } \\
\text { ornamentals }\end{array}$ & 2.67 & 0.000 & 0.000 & 0.00 & 0.00 & 0.00 & 0.00 \\
\hline agriculture - citrus fruits & 1.94 & 0.000 & 0.000 & 0.00 & 0.00 & 0.00 & 0.00 \\
\hline agriculture - coffee & 4.55 & 0.000 & 0.000 & 0.10 & 0.09 & 0.00 & 0.00 \\
\hline agriculture - cocoa & 3.72 & 0.000 & 0.000 & 0.00 & 0.00 & 0.00 & 0.00 \\
\hline agriculture - grapes & 2.85 & 0.000 & 0.000 & 0.00 & 0.00 & 0.00 & 0.00 \\
\hline agriculture - bananas & 4.57 & 0.000 & 0.000 & 0.00 & 0.00 & 0.00 & 0.00 \\
\hline agriculture - other & 6.44 & 0.007 & 0.000 & 0.04 & 0.04 & 5.93 & 6.56 \\
\hline agriculture - bovine animals & 3.48 & 0.000 & 0.000 & 0.00 & 0.00 & 0.00 & 0.00 \\
\hline agriculture - sheep & 7.58 & 0.000 & 0.000 & 0.00 & 0.00 & 0.00 & 0.00 \\
\hline agriculture - pigs & 4.72 & 0.000 & 0.000 & 0.00 & 0.00 & 0.00 & 0.00 \\
\hline agriculture - birds & 3.34 & 0.000 & 0.000 & 0.00 & 0.00 & 0.00 & 0.00 \\
\hline agriculture - beekeeping & 2.74 & 0.000 & 0.000 & 0.02 & 0.03 & 0.00 & 0.00 \\
\hline agriculture - silk & 6.08 & 0.000 & 0.000 & 0.00 & 0.00 & 0.24 & 0.22 \\
\hline agriculture - other animals & 5.32 & 0.000 & 0.000 & 0.04 & 0.05 & -0.01 & -0.02 \\
\hline forestry & 3.94 & 0.000 & 0.000 & 0.23 & 0.21 & 0.11 & 0.10 \\
\hline fishing and aquaculture & 3.13 & 0.000 & 0.000 & 0.00 & 0.00 & 0.00 & 0.00 \\
\hline mining - coal & 0.76 & -0.001 & 0.000 & 0.00 & 0.00 & -1.95 & -3.37 \\
\hline
\end{tabular}


Table B1 - Additional summary statistics - Child labor intensity and trade exposure measures by sector

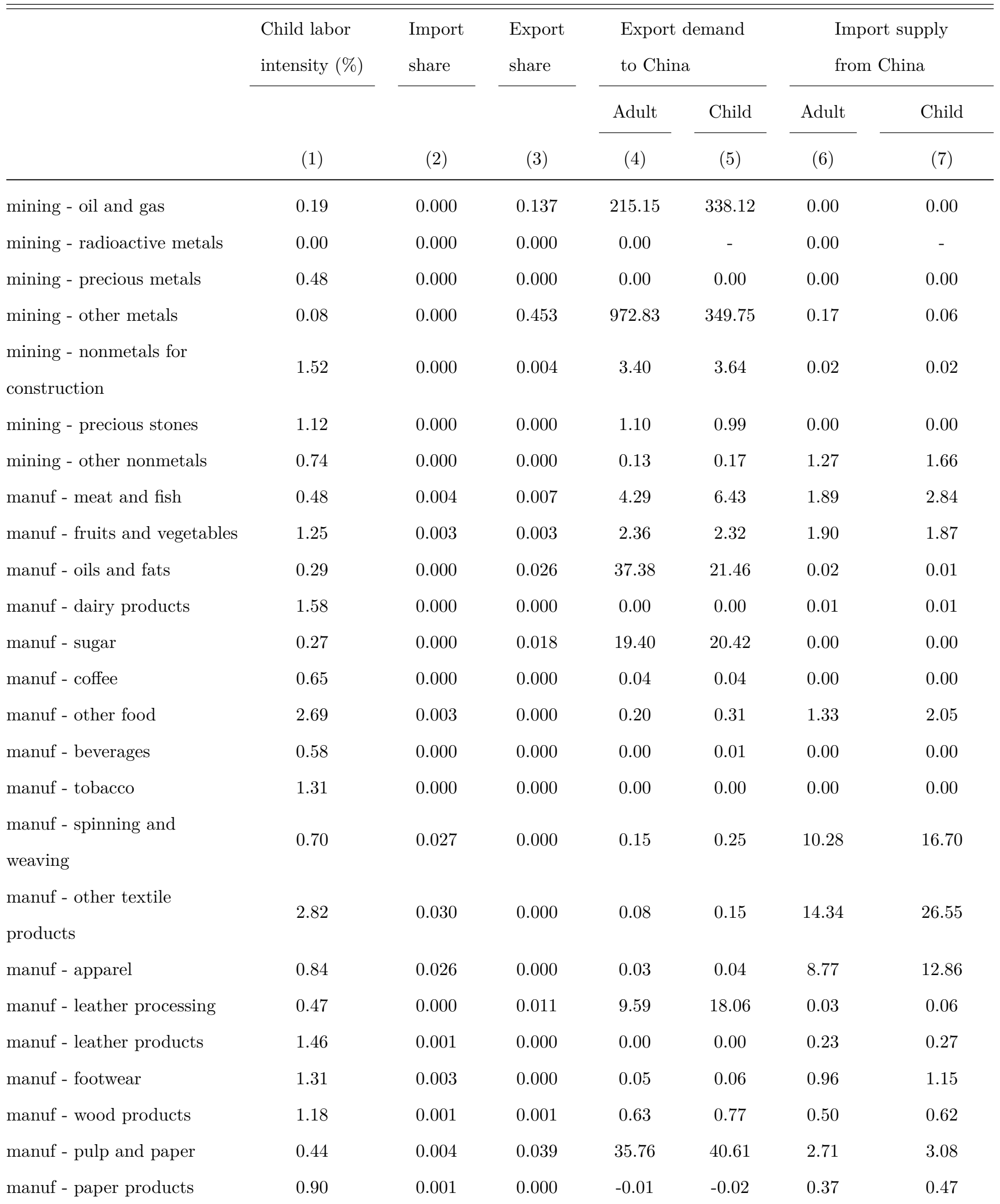


Table B1 - Additional summary statistics - Child labor intensity and trade exposure measures by sector

\begin{tabular}{|c|c|c|c|c|c|c|c|}
\hline & \multirow{2}{*}{$\begin{array}{l}\text { Child labor } \\
\text { intensity (\%) } \\
\text { (1) }\end{array}$} & \multirow{2}{*}{$\begin{array}{c}\text { Import } \\
\text { share } \\
\\
(2)\end{array}$} & \multirow{2}{*}{$\begin{array}{c}\text { Export } \\
\text { share } \\
\\
(3)\end{array}$} & \multicolumn{2}{|c|}{$\begin{array}{l}\text { Export demand } \\
\text { to China }\end{array}$} & \multicolumn{2}{|c|}{$\begin{array}{l}\text { Import supply } \\
\text { from China }\end{array}$} \\
\hline & & & & $(4)$ & $(5)$ & (6) & $(7)$ \\
\hline manuf - coke & 0.50 & 0.003 & 0.000 & 0.00 & 0.00 & 27.79 & 61.75 \\
\hline manuf - refined petroleum & 0.19 & 0.003 & 0.000 & 0.01 & 0.01 & 1.25 & 1.80 \\
\hline manuf - pharmaceuticals & 0.17 & 0.019 & 0.001 & 0.24 & 0.36 & 4.53 & 6.59 \\
\hline $\begin{array}{l}\text { manuf - cleaning and } \\
\text { hygiene products }\end{array}$ & 0.40 & 0.001 & 0.001 & 0.26 & 0.57 & 0.21 & 0.45 \\
\hline manuf - other chemicals & 0.37 & 0.069 & 0.008 & 3.91 & 5.54 & 28.54 & 40.48 \\
\hline manuf - rubber products & 0.38 & 0.014 & 0.000 & 0.13 & 0.22 & 4.12 & 6.86 \\
\hline manuf - plastic products & 0.37 & 0.025 & 0.000 & 0.06 & 0.07 & 7.22 & 7.75 \\
\hline manuf - glass products & 0.28 & 0.006 & 0.000 & 0.04 & 0.06 & 2.58 & 4.31 \\
\hline manuf - metal products & 0.60 & 0.030 & 0.001 & 0.17 & 0.27 & 7.11 & 11.63 \\
\hline manuf - machinery & 0.46 & 0.145 & 0.005 & 1.60 & 2.35 & 38.28 & 56.36 \\
\hline manuf - domestic appliances & 0.22 & 0.019 & 0.000 & 0.01 & 0.01 & 9.28 & 10.65 \\
\hline manuf - computing & 0.38 & 0.078 & 0.000 & 0.07 & 0.12 & 34.06 & 59.85 \\
\hline manuf - electrical equipment & 0.54 & 0.085 & 0.001 & 0.23 & 0.30 & 25.10 & 32.68 \\
\hline manuf - electronics & 0.33 & 0.205 & 0.001 & 0.52 & 0.93 & 70.19 & 125.89 \\
\hline manuf - medical instruments & 0.93 & 0.007 & 0.000 & 0.02 & 0.03 & 2.08 & 4.05 \\
\hline $\begin{array}{l}\text { manuf - measuring } \\
\text { instruments }\end{array}$ & 0.24 & 0.008 & 0.000 & 0.12 & 0.46 & 3.80 & 15.27 \\
\hline manuf - optical equipment & 0.47 & 0.022 & 0.000 & 0.16 & 0.22 & 10.29 & 14.24 \\
\hline manuf - watches and clocks & 0.00 & 0.002 & 0.000 & 0.00 & - & 2.11 & - \\
\hline
\end{tabular}


Table B1 - Additional summary statistics - Child labor intensity and trade exposure measures by sector

\begin{tabular}{|c|c|c|c|c|c|c|c|}
\hline & \multirow{2}{*}{$\begin{array}{l}\text { Child labor } \\
\text { intensity (\%) } \\
\text { (1) }\end{array}$} & \multirow{2}{*}{$\begin{array}{c}\text { Import } \\
\text { share } \\
\\
(2)\end{array}$} & \multirow{2}{*}{$\begin{array}{c}\text { Export } \\
\text { share } \\
\\
(3)\end{array}$} & \multicolumn{2}{|c|}{$\begin{array}{l}\text { Export demand } \\
\text { to China }\end{array}$} & \multicolumn{2}{|c|}{$\begin{array}{l}\text { Import supply } \\
\text { from China }\end{array}$} \\
\hline & & & & (4) & $(5)$ & (6) & $(7)$ \\
\hline $\begin{array}{l}\text { manuf - motor vehicle } \\
\text { bodies and parts }\end{array}$ & 0.29 & 0.012 & 0.002 & 0.62 & 1.11 & 3.32 & 5.91 \\
\hline manuf - shipbuilding & 0.65 & 0.000 & 0.000 & 0.00 & 0.00 & 0.05 & 0.03 \\
\hline manuf - other transport & 0.51 & 0.010 & 0.000 & 0.01 & 0.01 & 6.05 & 12.50 \\
\hline manuf - furniture & 1.21 & 0.005 & 0.000 & 0.00 & 0.00 & 1.89 & 2.41 \\
\hline manuf - other & 1.60 & 0.029 & 0.001 & 0.20 & 0.35 & 8.48 & 14.77 \\
\hline Non-tradeable & 1.13 & - & - & - & - & - & - \\
\hline
\end{tabular}

This table displays the mean across microregion of the sector-microregion-level of the child labor labor intensity in column (1), measured as the share of children among total workers, the share of each sector in the total growth of Brazil's imports and exports to China between 2000 and 2010 in columns (2) and (3) and the means across microregions of the sector-microregionlevel of the Brazil's import and exports to China, according to adult and child labor exposure. 
Table B2 - First-stage estimates (Main results) - Overall trade shocks

\begin{tabular}{lccc}
\hline \hline Dependent Variable & Import Competition & & Export Demand \\
\cline { 2 - 2 } & $(1)$ & $(2)$ \\
\hline iv Import Competition & $2.509^{* * *}$ & 0.034 \\
iv Export Demand & $(0.111)$ & $(0.279)$ \\
& $0.035^{*}$ & $1.678^{* * *}$ \\
F - Stat & $(0.021)$ & $(0.052)$ \\
Observations & 261.81 & 538.29 \\
\hline
\end{tabular}

This table displays first-stage estimates from estimating Equation (4.3) in Tables 3 and 4 using overall trade shocks (import competition and export demand) as dependent variables. All regressions include a constant and the following controls: 2000 workforce, 2000 share of workforce in agricultural sectors, 2000 share of workforce in extractive sectors, 2000 share of workforce in manufacturing, 2000 share of workforce in informal jobs, 2000 share of workforce in rural areas and microregion-level demographic controls such as the 2000 average household income, the 2000 average number of people living in the household, the 2000 percentage of a microregion's population that is nonwhite, the 2000 share of population that are female and college-educated, and the 2000 percentage of a microregion's population in 6 age groups. Regressions are weighted by the share of national children population in 2000. Standard errors are clustered by mesoregion, 91 clusters. ${ }^{*} p<0.1,{ }^{* *} p<0.05,{ }^{* * *} p<0.01$

Table B3 - First-stage estimates (Main results) - Disaggregated trade shocks

\begin{tabular}{|c|c|c|c|c|}
\hline \multirow[t]{2}{*}{ Dependent Variable } & $\begin{array}{l}\text { Import Shock - } \\
\text { Adult }\end{array}$ & $\begin{array}{l}\text { Import Shock - } \\
\text { Child }\end{array}$ & $\begin{array}{l}\text { Export Shock - } \\
\text { Adult }\end{array}$ & $\begin{array}{l}\text { Export Shock - } \\
\text { Child }\end{array}$ \\
\hline & (1) & $(2)$ & $(3)$ & (4) \\
\hline iv Import Competition Concentrated on Adult & $\begin{array}{c}2.506^{* * *} \\
(0.113)\end{array}$ & $\begin{array}{c}0.126 \\
(0.151)\end{array}$ & $\begin{array}{c}0.085 \\
(0.287)\end{array}$ & $\begin{array}{c}0.337 \\
(0.377)\end{array}$ \\
\hline iv Import Competition Concentrated on Child & $\begin{array}{c}0.010 \\
(0.040)\end{array}$ & $\begin{array}{c}2.267^{* * *} \\
(0.108)\end{array}$ & $\begin{array}{l}-0.089 \\
(0.062)\end{array}$ & $\begin{array}{l}-0.036 \\
(0.071)\end{array}$ \\
\hline iv Export Demand Concentrated on Adult & $\begin{array}{l}0.040^{*} \\
(0.023)\end{array}$ & $\begin{array}{c}0.001 \\
(0.018)\end{array}$ & $\begin{array}{c}1.714^{* * * *} \\
(0.053)\end{array}$ & $\begin{array}{l}-0.023 \\
(0.038)\end{array}$ \\
\hline iv Export Demand Concentrated on Child & $\begin{array}{l}-0.052 \\
(0.040)\end{array}$ & $\begin{array}{l}-0.100 \\
(0.067)\end{array}$ & $\begin{array}{l}-0.367 \\
(0.287)\end{array}$ & $\begin{array}{c}2.934^{* * *} \\
(0.699)\end{array}$ \\
\hline F - Stat & 145.69 & 111.66 & 343.84 & 5.53 \\
\hline Observations & 413 & 413 & 413 & 413 \\
\hline
\end{tabular}


Figure 1 - Geographical distributions of the trade shock measures across Brazilian microregions

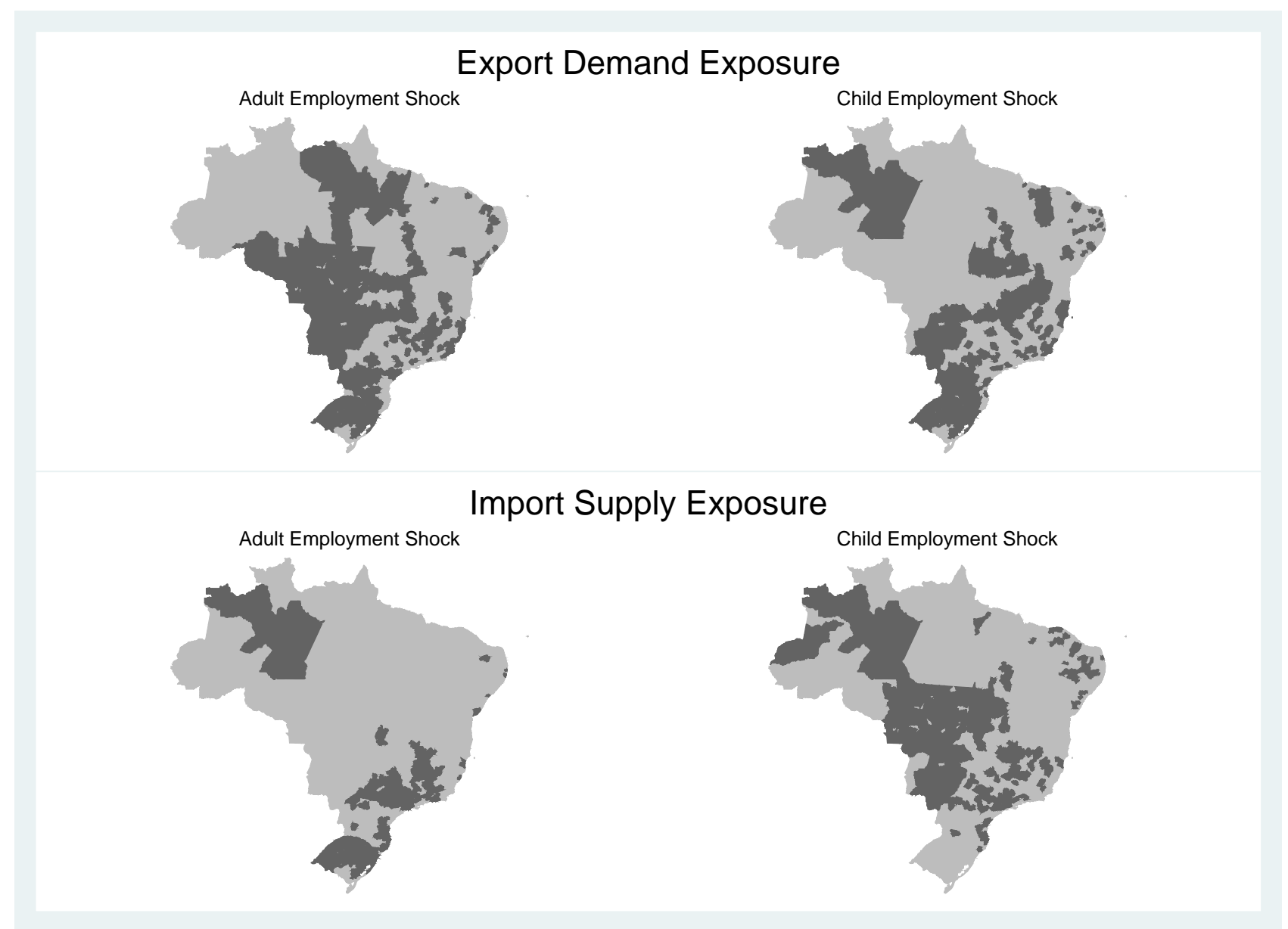

These maps display the geographical distributions of microregions in the top quartile of the overall and disaggregated import and export measures. 
Figure 2 - Distributions of overall and disaggregated trade shocks measures
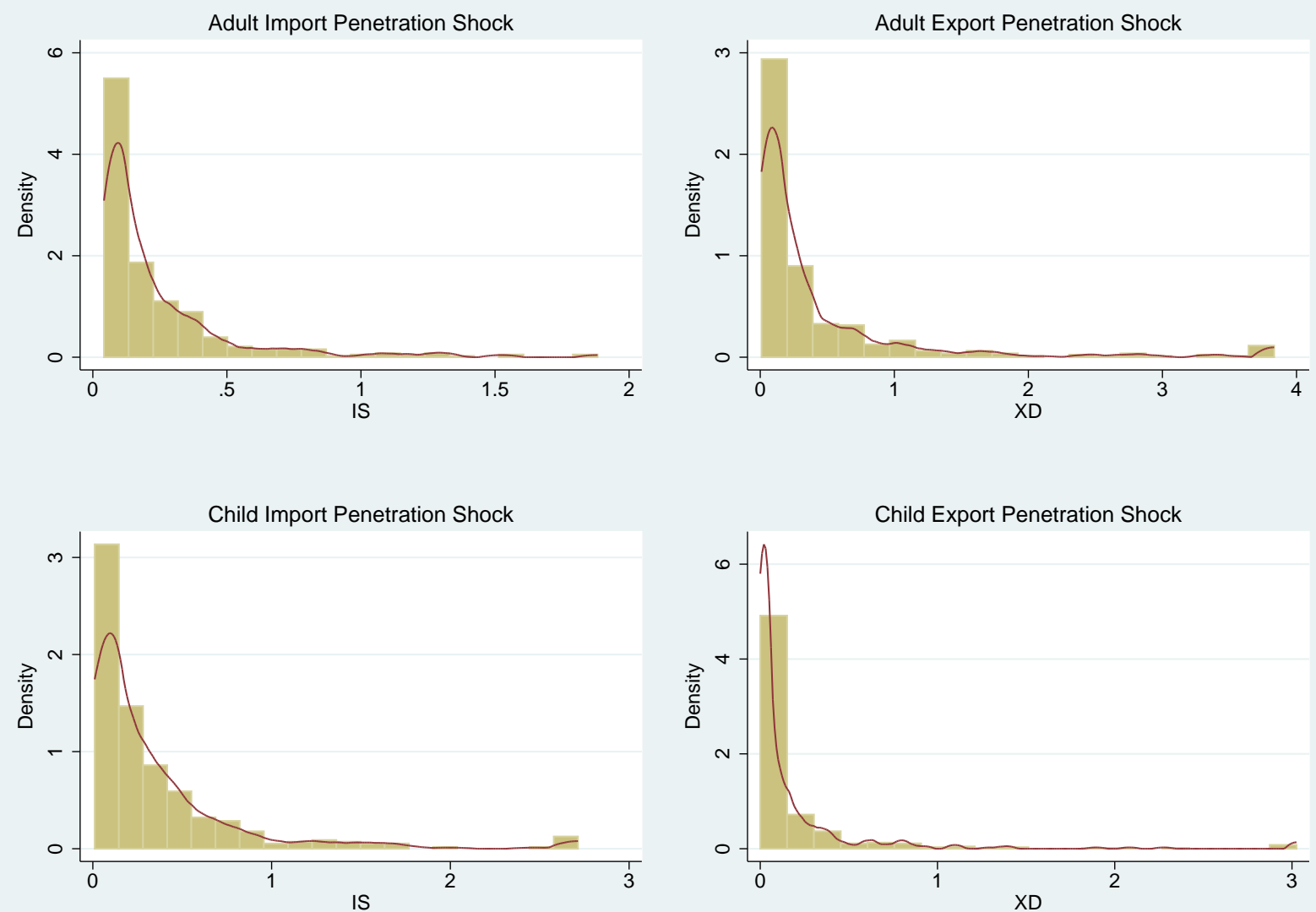

These graphs present the histogram of microregion-level import competition and export demand shocks (overall and disaggregated by age), in thousands of US dollars per worker. 